\title{
OVERCOMING THE EFFECTS OF DIFFERENTIAL SKEWNESS OF TEST ITEMS IN SCALE CONSTRUCTION
}

\author{
JOHANN M SCHEPERS \\ Department of Human Resource Management \\ Rand Afrikaans University
}

\begin{abstract}
The principal objective of the study was to develop a procedure for overcoming the effects of differential skewness of test items in scale construction. It was shown that the degree of skewness of test items places an upper limit on the correlations between the items, regardless of the contents of the items. If the items are ordered in terms of skewness the resulting intercorrelation matrix forms a simplex or a pseudo simplex. Factoring such a matrix results in a multiplicity of factors, most of which are artefacts. A procedure for overcoming this problem was demonstrated with items from the Locus of Control Inventory (Schepers, 1995). The analyses were based on a sample of 1662 firstyear university students.
\end{abstract}

\section{OPSOMMING}

Die hoofdoel van die studie was om 'n prosedure te ontwikkel om die gevolge van differensiële skeefheid van toetsitems, in skaalkonstruksie, teen te werk. Daar is getoon dat die graad van skeefheid van toetsitems 'n boonste grens plaas op die korrelasies tussen die items ongeag die inhoud daarvan. Indien die items gerangskik word volgens graad van skeefheid, sal die interkorrelasiematriks van die items 'n simpleks of pseudosimpleks vorm. Indien so 'n matriks aan faktorontleding onderwerp word, lei dit tot ' $\mathrm{n}$ veelheid van faktore waarvan die meerderheid artefakte is. 'n Prosedure om hierdie probleem te bowe te kom, is gedemonstreer met behulp van die items van die Lokus van Beheer-vraelys (Schepers, 1995). Die ontledings is op 'n steekproef van 1662 eerstejaaruniversiteitstudente gebaseer.

In the construction of psychometric tests it is normally assumed that the items included in a test form a linear scale. To test this assumption the dimensionality of the vector space of test items must first be determined. Should it turn out to be multidimensional, the test items must first be categorised according to the construct measured. The categorisation of the test items can be done with the aid of factor analysis, but the procedure is not free of problems.

The gist of the problem concerns the fact that test items usually vary in terms of their degree of skewness (i.e. are differentially skew), and this affects their mutual intercorrelations. If test items that are differentially skew are subjected to factor analysis, a multiplicity of factors is usually obtained. This tends to obscure the true structure of the intercorrelation matrix of test items (cf. Ferguson, 1941).

To illustrate the problem, binary items (i.e. items scored dichotomously), with different marginal splits, will be used. Thereafter the principle will be generalised to items where the responses are endorsed on continuous scales (usually five or seven-point scales) which are often differentially skew. But to start off with the concept 'marginal split' will first be clarified:

If test items are scored dichotomously, the proportion of respondents endorsing an item according to the scoring key $\left(\mathrm{p}_{\mathrm{g}}\right)$ and the proportion of respondents not endorsing the item according to the scoring key $\left(\mathrm{q}_{\mathrm{g}}\right)$, will vary from item to item. The ratio of $\mathrm{p}_{\mathrm{g}}$ to $\mathrm{q}_{\mathrm{g}}$ is usually referred to as the marginal split of item ${ }_{\mathrm{g}}$. In the general literature $\mathrm{p}_{\mathrm{g}}$ is usually referred to as the 'difficulty value' of item $\mathrm{g}$. For convenience sake, the expression 'p-value' will be used in this paper.

In Table 1 the maximum intercorrelations of 10 test items with different marginal splits are given. The items have been arranged according to their marginal distributions from $0,05: 0,95$ to 0,95:0,05.

From Table 1 it is evident that there is a clear gradient underlying the intercorrelations: adjacent items correlate the highest with one another, for example items 1 and 2, whilst items that are far apart, for example items 1 and 10, correlate the lowest. The highest intercorrelations are adjacent to the principal diagonal

Requests for copies should be addressed to: JM Schepers, Department of Human

Resource Management, RAU, PO Box 524, Auckland Park, 2006 and systematically taper off as you move away from the principal diagonal. This is true for both the rows and the columns of the intercorrelation matrix. Such intercorrelation matrices are known as simplexes, and must not be confused with ordinary unidimensional intercorrelation matrices.

The inverse of a simplex has rather special properties: the principal diagonal is positive and the two adjacent diagonals are negative. All the other elements are equal to zero (Guttman, 1954, 1955, 1957; Schepers, 1962; Jöreskog, 1970).

The inverse of the intercorrelation matrix in Table 1 is given in Table 2 .

From Table 2 it is clear that the inverse of the intercorrelation matrix, in Table 1 , reveals all the properties of a simplex. The implications of this will now be carefully scrutinised.

The significance of a simplex structure is clearest if the standardised multiple regression coefficients for predicting each variable (item) by the rest, are viewed. In the case of a perfect simplex only adjacent variables can be used to predict a particular variable. The regression coefficients of all the other variables are equal to zero.

The regression coefficients for predicting each variable by the rest, in respect of Table 1, are given in Table 3 (cf. Schepers, 1962, p. 301).

From Table 3 it can be seen that the regression coefficients in the two diagonals adjacent to the principal diagonal vary from 0,3052 to 0,6063 . All the other coefficients are equal to zero.

As mentioned earlier, the intercorrelation matrix in Table 1 represents the maximum intercorrelations of 10 test items with specified marginal distributions. Furthermore, the assumption was made that all the items relate to a single central construct (Bohrnstedt \& Knoke, 1988; Gorsuch, 1974; Guilford, 1950; Magnusson, 1967). It would therefore be logical to expect a single factor underlying the matrix of intercorrelations. The structure of the intercorrelation matrix was accordingly investigated.

The eigenvalues of the unreduced intercorrelation matrix are given in Table 4. 
TABLE 1

IINTERCORRELATION MATRIX OF TEST ITEMS WITH DIFFERENT DEGREES OF SKEWNESS

\begin{tabular}{|c|c|c|c|c|c|c|c|c|c|c|}
\hline & 1 & 2 & 3 & 4 & 5 & 6 & 7 & 8 & 9 & 10 \\
\hline 1 & 1,0000 & 0,5461 & 0,3974 & 0,3126 & 0,2536 & 0,2075 & 0,1683 & 0,1325 & 0,0964 & 0,0526 \\
\hline 2 & 0,5461 & 1,0000 & 0,7276 & 0,5725 & 0,4644 & 0,3800 & 0,3083 & 0,2425 & 0,1765 & 0,0964 \\
\hline 3 & 0,3974 & 0,7276 & 1,0000 & 0,7868 & 0,6383 & 0,5222 & 0,4237 & 0,3333 & 0,2425 & 0,1325 \\
\hline 4 & 0,3126 & 0,5725 & 0,7868 & 1,0000 & 0,8112 & 0,6637 & 0,5385 & 0,4237 & 0,3083 & 0,1683 \\
\hline 5 & 0,2536 & 0,4644 & 0,6383 & 0,8112 & 1,0000 & 0,8182 & 0,6637 & 0,5222 & 0,3800 & 0,2075 \\
\hline 6 & 0,2075 & 0,3800 & 0,5222 & 0,6637 & 0,8182 & 1,0000 & 0,8112 & 0,6383 & 0,4644 & 0,2536 \\
\hline 7 & 0,1683 & 0,3083 & 0,4237 & 0,5385 & 0,6637 & 0,8112 & 1,0000 & 0,7868 & 0,5725 & 0,3126 \\
\hline 8 & 0,1325 & 0,2425 & 0,3333 & 0,4237 & 0,5222 & 0,6383 & 0,7868 & 1,0000 & 0,7276 & 0,3974 \\
\hline 9 & 0,0964 & 0,1765 & 0,2425 & 0,3083 & 0,3800 & 0,4644 & 0,5725 & 0,7276 & 1,0000 & 0,5461 \\
\hline 10 & 0,0526 & 0,0964 & 0,1325 & 0,1683 & 0,2075 & 0,2536 & 0,3126 & 0,3974 & 0,5461 & 1,0000 \\
\hline$s_{g}$ & 0,2179 & 0,3571 & 0,4330 & 0,4770 & 0,4975 & 0,4975 & 0,4770 & 0,4330 & 0,3571 & 0,2179 \\
\hline$p_{g}$ & 0,05 & 0,15 & 0,25 & 0,35 & 0,45 & 0,55 & 0,65 & 0,75 & 0,85 & 0,95 \\
\hline $\mathrm{q}_{\mathrm{g}}$ & 0,95 & 0,85 & 0,75 & 0,65 & 0,55 & 0,45 & 0,35 & 0,25 & 0,15 & 0,05 \\
\hline
\end{tabular}

Note: $s_{g}=\sqrt{p_{g} q_{g}}, r_{p h i}=\frac{p_{g k}-p_{g} p_{k}}{s_{g} s_{k}}$

TABLE 2

INVERSE OF INTERCORRELATION MATRIX

\begin{tabular}{|c|c|c|c|c|c|c|c|c|c|c|}
\hline & 1 & 2 & 3 & 4 & 5 & 6 & 7 & 8 & 9 & 10 \\
\hline 1 & 1,4250 & $-0,7782$ & & & & & & & & \\
\hline 2 & $-0,7782$ & 2,5500 & $-1,5462$ & & & & & & & \\
\hline 3 & & $-1,5462$ & 3,7500 & $-2,0653$ & & & & & & \\
\hline 4 & & & $-2,0653$ & 4,5500 & $-2,3729$ & & & & & \\
\hline 5 & & & & $-2,3729$ & 4,9500 & $-2,4750$ & & & & \\
\hline 6 & & & & & $-2,4750$ & 4,9500 & $-2,3729$ & & & \\
\hline 7 & & & & & & $-2,3729$ & 4,5500 & $-2,0653$ & & \\
\hline 8 & & & & & & & $-2,0653$ & 3,7500 & $-1,5462$ & \\
\hline 9 & & & & & & & & $-1,5462$ & 2,5500 & $-0,7782$ \\
\hline 10 & & & & & & & & & $-0,7782$ & 1,4250 \\
\hline
\end{tabular}

TABLe 3

STANDARDISED MULTIPLE REGRESSION COEFFICIENTS FOR PREDICTING EACH ITEM BY THE REST

\begin{tabular}{|c|c|c|c|c|c|c|c|c|c|c|}
\hline & 1 & 2 & 3 & 4 & 5 & 6 & 7 & 8 & 9 & 10 \\
\hline 1 & - & 0,5461 & & & & & & & & \\
\hline 2 & 0,3052 & - & 0,6063 & & & & & & & \\
\hline 3 & & 0,4123 & - & 0,5508 & & & & & & \\
\hline 4 & & & 0,4539 & - & 0,5215 & & & & & \\
\hline 5 & & & & 0,4794 & - & 0,5000 & & & & \\
\hline 6 & & & & & 0,5000 & - & 0,4794 & & & \\
\hline 7 & & & & & & 0,5215 & - & 0,4539 & & \\
\hline 8 & & & & & & & 0,5508 & - & 0,4123 & \\
\hline 9 & & & & & & & & 0,6063 & - & 0,3052 \\
\hline 10 & & & & & & & & & 0,5461 & \\
\hline
\end{tabular}


TABLE 4

EIGENVALUES OF INTERCORRELATION MATRIX

\begin{tabular}{cc}
\hline Root & Eigenvalue \\
\hline 1 & $\mathbf{5 , 0 7 5 2}$ \\
2 & $\mathbf{1 , 7 9 2 9}$ \\
3 & $\mathbf{1 , 0 0 0 5}$ \\
4 & 0,6704 \\
5 & 0,4671 \\
6 & 0,3281 \\
7 & 0,2374 \\
8 & 0,1785 \\
9 & 0,1389 \\
10 & 0,1111 \\
\hline Trace & 10,000 \\
\hline
\end{tabular}

From Table 4 it is clear that there are three eigenvalues greater than unity. Accordingly three factors were postulated (Kaiser, 1961).

Next, the intercorrelation matrix was subjected to a principal factor analysis. Three factors were extracted and rotated to simple structure by means of a Varimax rotation. The rotated factor matrix is given in Table 5 .

\section{TABle 5}

ROTATED FACTOR MATRIX (VARIMAX)

\begin{tabular}{lcccc}
\hline Variable & Factor $\mathbf{1}$ & Factor 2 & Factor 3 & $\mathbf{h}_{\mathbf{j}}^{2}$ \\
\hline 1 & 0,071 & $\mathbf{0 , 5 4 5}$ & 0,060 & 0,3056 \\
2 & 0,192 & $\mathbf{0 , 8 7 4}$ & 0,092 & 0,8088 \\
3 & 0,464 & $\mathbf{0 , 7 3 0}$ & 0,083 & 0,7553 \\
4 & $\mathbf{0 , 6 7 6}$ & 0,542 & 0,114 & 0,7643 \\
5 & $\mathbf{0 , 8 2 2}$ & 0,347 & 0,192 & 0,8322 \\
6 & $\mathbf{0 , 8 2 2}$ & 0,192 & 0,347 & 0,8322 \\
7 & $\mathbf{0 , 6 7 6}$ & 0,114 & 0,542 & 0,7643 \\
8 & 0,464 & 0,083 & $\mathbf{0 , 7 3 0}$ & 0,7553 \\
9 & 0,192 & 0,092 & $\mathbf{0 , 8 7 4}$ & 0,8088 \\
10 & 0,071 & 0,060 & $\mathbf{0 , 5 4 5}$ & 0,3056 \\
\hline
\end{tabular}

Table 5 shows that items 4, 5, 6 and 7 have high loadings on Factor 1, whilst items 1, 2 and 3 have high loadings on Factor 2. Items 8, 9 and 10 have high loadings on Factor 3. Items 1, 2 and 3 have p-values between 0,05 and 0,25 ; items $4,5,6$ and 7 have p-values between 0,35 and 0,65, and items 8,9 and 10 have pvalues between 0,75 and 0,95 . The items therefore cluster according to their marginal distributions.

It is also striking that the communalities of items 1 and 10 are considerably lower than the rest. This phenomenon is typical of simplexes, because in a simplex it is only adjacent items that share common variance, and the first and the last items have only one adjacent item each.

All the limitations that have been referred to above are the direct consequence of the simplex structure of the particular intercorrelation matrix. But the most troublesome aspect is the artefactual factors that emerge if a simplex is subjected to a principal factor analysis. In the present case there were only three factors, but it is not uncommon to obtain a multiplicity of factors, particularly in respect of large matrices.
Different solutions have already been proposed to overcome the problem of artefactual factors. Gorsuch (1974, p. 262), for instance, maintains that the best solution is to avoid working with variables that are too skew. His suggestion is highly acceptable, provided the variables used derive from well constructed measuring instruments. Where necessary the obtained scores can even be normalised before doing a factor analysis. But when working with test items his suggestion is not acceptable. The discrimination power and reliability of a test will be lowered if all the items have equal p-values. A wide distribution of p-values $(0,10$ to 0,90$)$ is necessary to ensure good discrimination power and reliability. The rationale for this should be apparent from an analysis of Kuder-Richardson Formula 20 (Kuder \& Richardson, 1937). The derivation of the formula is given in Appendix 1.

$K R_{20}=\frac{K}{K-1}\left[1-\frac{\mu-\frac{\mu^{2}}{K}-K \sigma_{p}^{2}}{\sigma_{x}^{2}}\right]$, where

$K=$ number of test items

$m=$ mean of test

$p_{g}=$ proportion of subjects endorsing item $\mathrm{g}$ according to the key $\sigma_{p}^{2}=$ variance of $p_{g}{ }^{\prime} \mathrm{s}$

The larger $K \sigma_{\mathrm{p}}^{2}$, the larger the test reliability would be (Horst, 1953).

Tucker $(1949$, p. 119) has shown that the variance of the p-values for a rectangular distribution of the $p_{g}$ 's, varying from 0,00 to 1,00 , is equal to 0,083 . For a normal distribution with $\mathrm{p}=0,00$ at $-3 \sigma$ and $\mathrm{p}=1,00$ at $+3 \sigma$, the variance is equal to 0,028 .

From the foregoing it is clear that for a longer test or scale, with a wide distribution of $p_{g}{ }^{\prime} \mathrm{s}$, the value of $K \sigma_{\mathrm{p}}{ }^{2}$ can be quite substantial.

Formula 1 applies only to binary data.

For continuous data, Kuder-Richardson Formula 20 and Cronbach's coefficient alpha (Cronbach, 1951), can be used. The transformed $K R_{20}$ formula can be written as follows:

$K R_{20}=\left[1-\frac{K \sum_{g=1}^{k} \sigma_{g}^{2}-\sigma_{x}^{2}}{(K-1) \sigma_{x}^{2}}\right]$,

where

$K=$ number of test items

$\sum_{g=1}^{K} \sigma_{g}^{2}=$ sum of item variances

$\sigma_{x}^{2}=$ test variance

[The derivation of Formula 2 is given in Appendix 1].

The total test variance can never exceed $K \sum_{g=1}^{K} \sigma_{g}^{2}$ (cf. Schepers, 1992, p. 33), therefore, the greater the test variance, the higher the reliability will be.

From the foregoing it is clear that Gorsuch's suggestion of avoiding items that are too skew, will lead to a reduction in test reliability. 
Horst (1965, p. 516) maintained that one way of getting rid of the artefactual factors is to fit an appropriate simplex to the binary data matrix and to separate it from the true structure. This is equivalent to throwing the baby away with the bath water.

The fitting of a simplex poses problems of its own. Firstly, an appropriate model must be decided upon, and then an appropriate method must be found to fit the model to the data. If the measuring units of all the variables are the same, a simplex can be fitted to the variance-covariance matrix, but if the units of measurement differ, the intercorrelation matrix must be used (Jöreskog, 1970).

Jöreskog (1970, p. 122) distinguishes six different simplex models. These models can broadly be divided into Markov simplexes and Wiener simplexes. The Markov simplexes can be subdivided into perfect simplexes, quasi-simplexes and restricted quasi-simplexes. Similarly, Wiener simplexes can be subdivided into perfect simplexes, quasi-simplexes and quasi-simplexes with equal error variances. Markov simplexes are scale free, i.e. the measuring units of the variables do not have to be the same. Wiener simplexes, on the other hand, are scale dependent, ie. they can only be used if the units of measurement of all the variables are the same (Jöreskog, 1970, p. 128).

Perfect simplexes only arise if true scores are used. The moment there is measurement error it becomes a quasi-simplex. According to Jöreskog (1970, p. 130) the fitting of a perfect simplex is straightforward, but the fitting of quasi-simplexes is complex and requires iterative procedures. Reasonable fits can be obtained with the LISREL-program (Jörgeskog \& Sorbom, 1982).

There are many intercorrelation matrices that superficially resemble simplexes, but that are really pseudo-simplexes. This complicates the issue of fitting simplexes even further. It is also doubtful whether the fitting of a simplex overcomes the problem of differential skewness, and the generation of 'difficulty factors'.

So far the research problem has been developed in terms of binary items that are differentially skew. It will now be broadened to continuous items that are differentially skew.

The principal objectives of the present study were to:

1. Examine the gradients of the correlations (by row and by column) in an intercorrelation matrix based on continuous variables, arranged in terms of degree of skewness.

2. Determine the factor structure of an intercorrelation matrix based on continuous variables, arranged in terms of degree of skewness.

3. Develop and evaluate a procedure for overcoming the effects of differential skewness on the factor structure of test items, and to examine the properties of the resulting scales.

\section{METHOD}

\section{Sample}

The full complement of first-year university students at the Rand Afrikaans University, during 1995, was subjected to an extensive psychometric test programme. The programme stretched over four days, and to ensure complete records, students who did not attend all the test sessions were excluded from the sample. The final sample consisted of 1662 students, and can be considered representative of the population of firstyear university students at the Rand Afrikaans University, during 1995. The ages of the students varied from 26 to 54 years, with a mean of 27,30 years and a standard deviation of 1,842 years. As far as gender is concerned $49,8 \%$ were female and $47,2 \%$ were male. Missing information accounted for 3,0\%. The majority of the students were Afrikaans-speaking (969). Three hundred and seventy nine were English-speaking, and 195 spoke both English and Afrikaans. Only 27 had an African language as vernacular. Thirty-nine spoke other languages, and 53 did not indicate their home language. As far as ethnic group is concerned $88,7 \%$ were White, $1,4 \%$ were Indian, $4,7 \%$ were Coloured and 2,2\% were African.

\section{Measuring instrument}

For the purpose of this study the items of the Locus of Control Inventory (Schepers, 1995), were used.

The construct of 'locus of control' was created by Rotter (1966) and pertains to a person's expectation of reinforcement of his/her behaviour, arising from the social environment. Therefore, it is theoretically based on social learning theory (Mischel, 1979). Rotter (1966) distinguished between two different orientations in people, namely an internal control orientation and an external control orientation. People with an internal control orientation are convinced that their behaviour depends on their own achievements, abilities and dedication, whereas people with an external control orientation believe that random or fortuitous events, fate, Lady Luck and certain influential people are responsible for their behaviour.

Conceptually, the Locus of Control Inventory (LCI) is based on attribution theory and social learning theory. People are constantly attuned to finding the causes of their behaviour and those of others. The attributing of causes to specific behaviour is called attributions. The causative attributions that people make and their interpretation thereof determine their perceptions of the social world to a large extent. Is it a friendly or a hostile world? Is it a just or unjust world? Is it a predictable or an unpredictable world? Can we exercise control over certain events through our own abilities or are our lives controlled by certain influential people? According to attribution theory the causes of human behaviour can be divided into two broad categories, namely dispositional causes and situational causes. Dispositional causes pertain to one's natural disposition and include the organismic attributes of people. Situational causes pertain to the external world and include all environmental factors (Roediger III et al., 1991).

Social learning theory links up with attribution theory: whereas social learning theory deals with the nature of reinforcements arising from the social behaviour of the learner, attribution theory pertains to the way in which a person gathers information about the stable or invariant characteristics of others - their motives, intentions and traits - as well as the external world (Baron, Byrne \& Kantowitz, 1980).

A construct closely related to internal control is autonomy. Autonomy can be defined as 'the tendency to attempt to master or be effective in the environment, to impose one's wishes and designs on it' (Wolman, 1973, p. 37). It is expected that persons high on autonomy would seek control of situations that offer possibilities of change, would readily accept the challenge of solving complex problems, would take the initiative in situations requiring leadership, would prefer to work on their own and to structure their own work programme.

With attribution theory and social learning theory as frames of reference, the domain of locus of control was extensively sampled. Altogether 80 items were written, representing the constructs of internal control, external control and autonomy. Roughly equal numbers of items were written in respect of each of the constructs.

The items of the LCI are all in the form of questions and the responses are endorsed on a seven-point scale. Only the end-points of the scales are verbally anchored. Separate answer sheets that can be read by an optical page reader are used, and the responses can be read directly onto a stiffy or compact disk. 
Procedure

The LCI was applied to the full complement of firstyear university students at the Rand Afrikaans University during 1995. Thereafter the answer sheets were carefully scrutinised for double markings or incompleteness. Where necessary the markings were made clearer and stray marks were erased. If more than two items were left blank or spoilt, the person's record was not used. If one or two items were left blank or spoilt, the person's mean for that construct (according to the a priori key) was estimated, and his/her item mean was substituted for the particular item. Care was taken not to estimate item means if several respondents skipped the same item. In this way 1662 complete records were obtained.

\section{Statistical analysis}

In order to examine the gradients of the correlations in an intercorrelation matrix of continuous variables that have been arranged according to their degree of skewness, the means, standard deviations, coefficients of skewness and kurtosis of the 80 items of the LCI were computed. Next, the items were arranged according to their degree of skewness. To ensure stability of the data, composite scores were formed by adding the scores of eight adjacent items together. In this way 10 new variables were formed The 10 new variables were then intercorrelated. Following this the inverse of the obtained intercorrelation matrix was computed.

To determine the factor structure of an intercorrelation matrix based on continuous variables arranged in terms of degree of skewness, the same data as above were used, except that the subscores were based on parcels of four adjacent items instead of eight. The resulting 20 subscores were then intercorrelated and subjected to a principal factor analysis. The obtained factor matrix was rotated to simple structure by means of a Direct Oblimin rotation.

To overcome the effects of differential skewness of the items of the LCI, the following procedure (as suggested in Schepers, 1992) was followed:

1. The 80 items were intercorrelated.

2. The eigenvalues of the unreduced intercorrelation matrix were calculated.

3. As many factors as there were eigenvalues greater than unity were postulated.

4. An iterative principal factor analysis was done.

5. Iteration was done on the number of factors as determined at step 3.

6. The obtained factor matrix was rotated to simple structure by means of a Varimax rotation.

7. All the items with high negative loadings were reflected.

8. All the items with high loadings on a specific factor were added together and a subscore for each factor was computed. Every item was used only once.

9. The obtained subscores were intercorrelated and steps 2 to 4 were repeated.

10. The obtained factor matrix was rotated to simple structure by means of a Direct Oblimin rotation.

11. All subscores with negative loadings on the first principal axis were reflected.

12. Separate scales were formed, corresponding to each of the factors, by grouping all the items together that had substantial loadings on a factor, ie. all the items in the relevant subscores (cf. step 8).

13. Separate item analyses (NP50) were done for each of the scales formed.

14. Iteration was done in terms of the indices of reliability of the test items.

15. The reliability of the scales were determined by means of Cronbach's coefficient alpha.

\section{RESULTS}

Objective 1: Gradients of correlations in an intercorrelation matrix based on continuous variables, arranged in terms of skewness

As a first step, the means, standard deviations, and coefficients of skewness of the 80 items of the LCI were computed. Next, the items were arranged according to their degree of skewness. The descriptive statistics are given in Table 6 .

TABLE 6

MEANS, STANDARD DEVIATIONS AND COEFFICIENTS OF SKEWNESS OF THE TEST ITEMS

\begin{tabular}{|c|c|c|c|c|}
\hline & Variable & Mean & $\begin{array}{l}\text { Standard } \\
\text { deviation }\end{array}$ & $\begin{array}{c}\text { Coefficient } \\
\text { of skewness }\end{array}$ \\
\hline \multirow[t]{8}{*}{ New variable 1} & Q19 & 6,3285 & 0,8537 & $-1,7592$ \\
\hline & Q60 & 6,1330 & 1,1200 & $-1,6226$ \\
\hline & Q61 & 5,9675 & 1,1309 & $-1,6141$ \\
\hline & Q42 & 6,1005 & 1,0588 & $-1,5781$ \\
\hline & Q37 & 5,9537 & 1,0426 & $-1,4967$ \\
\hline & Q18 & 6,0632 & 1,0177 & $-1,4407$ \\
\hline & Q49 & 6,2202 & 0,8993 & -14065 \\
\hline & Q10 & 6,1258 & 0,9300 & $-1,2905$ \\
\hline \multirow[t]{8}{*}{ New variable 2} & Q63 & 6,1943 & 0,9003 & $-1,2590$ \\
\hline & Q75 & 5,9693 & 1,0867 & $-1,2468$ \\
\hline & Q59 & 5,7443 & 1,3507 & 1,2163 \\
\hline & Q31 & 5,8207 & 1,1219 & $-1,1491$ \\
\hline & Q13 & 5,7966 & 0,9513 & $-1,0591$ \\
\hline & Q62 & 5,6227 & 1,2052 & $-1,0363$ \\
\hline & Q28 & 5,4633 & 1,3655 & $-1,0208$ \\
\hline & Q8 & 5,6071 & 1,1489 & $-1,0048$ \\
\hline \multirow[t]{8}{*}{ New variable 3} & Q22 & 5,8039 & 1,1023 & $-0,9947$ \\
\hline & Q16 & 5,1799 & 1,6189 & $-0,9934$ \\
\hline & Q67 & 5,7635 & 1,0554 & $-0,9602$ \\
\hline & Q66 & 6,0897 & 0,9021 & $-0,9457$ \\
\hline & Q69 & 5,7419 & 1,1072 & $-0,9350$ \\
\hline & Q48 & 5,3538 & 1,3030 & $-0,9026$ \\
\hline & Q24 & 5,4398 & 1,2491 & $-0,8827$ \\
\hline & Q54 & 5,4266 & 1,1774 & $-0,8541$ \\
\hline \multirow[t]{8}{*}{ New variable 4} & Q40 & 5,3057 & 1,3288 & $-0,8485$ \\
\hline & Q2 & 5,4940 & 1,2772 & $-0,8381$ \\
\hline & Q73 & 5,1986 & 1,2821 & $-0,8258$ \\
\hline & Q70 & 5,6492 & 1,2166 & $-0,8215$ \\
\hline & Q6 & 5,6859 & 1,0957 & $-0,8036$ \\
\hline & Q68 & 5,7389 & 1,0071 & $-0,7734$ \\
\hline & Q46 & 5,3995 & 1,1133 & $-0,7371$ \\
\hline & Q76 & 5,0235 & 1,5189 & $-0,7322$ \\
\hline \multirow[t]{8}{*}{ New variable 5} & Q55 & 5,5890 & 1,0004 & $-0,7082$ \\
\hline & Q27 & 5,6227 & 1,0881 & $-0,6982$ \\
\hline & Q7 & 5,6637 & 1,0453 & $-0,6947$ \\
\hline & Q17 & 5,3153 & 1,2883 & $-0,6697$ \\
\hline & Q29 & 5,2882 & 1,2113 & $-0,6390$ \\
\hline & Q32 & 5,2515 & 1,2339 & $-0,6214$ \\
\hline & Q30 & 5,2058 & 1,3249 & $-0,6133$ \\
\hline & Q25 & 5,2744 & 1,3027 & $-0,6092$ \\
\hline \multirow[t]{8}{*}{ New variable 6} & Q14 & 5,2010 & 1,1651 & $-0,6063$ \\
\hline & Q74 & 5,2100 & 1,1291 & $-0,6023$ \\
\hline & Q5 & 5,2557 & 1,0171 & $-0,5963$ \\
\hline & Q44 & 5,1871 & 1,0226 & $-0,5259$ \\
\hline & Q39 & 4,7786 & 1,3998 & $-0,5103$ \\
\hline & Q9 & 5,0391 & 1,2906 & $-0,5086$ \\
\hline & Q26 & 4,6546 & 1,5714 & $-0,4864$ \\
\hline & Q1 & 4,7960 & 1,3723 & $-0,4761$ \\
\hline
\end{tabular}




\begin{tabular}{|c|c|c|c|c|}
\hline \multirow[t]{8}{*}{ New variable 7} & Q64 & 4,3454 & 1,2960 & $-0,4112$ \\
\hline & Q50 & 4,7569 & 1,3762 & $-0,3913$ \\
\hline & Q47 & 4,6191 & 1,4449 & $-0,3822$ \\
\hline & Q15 & 4,6907 & 1,5028 & $-0,3266$ \\
\hline & Q3 & 4,5000 & 1,3634 & $-0,3011$ \\
\hline & Q77 & 4,3063 & 1,7838 & $-0,2711$ \\
\hline & Q71 & 4,4302 & 1,2917 & $-0,1796$ \\
\hline & Q51 & 3,6516 & 1,3752 & $-0,0815$ \\
\hline \multirow[t]{8}{*}{ New variable 8} & Q72 & 4,2942 & 1,3370 & $-0,0414$ \\
\hline & Q65 & 3,7100 & 1,6761 & $-0,0330$ \\
\hline & Q80 & 3,6342 & 1,5409 & 0,0431 \\
\hline & Q38 & 3,5812 & 1,4367 & 0,1515 \\
\hline & Q20 & 33965 & 1,3670 & 0,1660 \\
\hline & Q4 & 3,6203 & 1,8354 & 0,1662 \\
\hline & Q21 & 3,4260 & 1,3251 & 0,1872 \\
\hline & Q57 & 3,2816 & 1,4653 & 0,2859 \\
\hline \multirow[t]{8}{*}{ New variable 9} & Q36 & 3,1949 & 1,4547 & 0,2941 \\
\hline & Q43 & 3,1270 & 1,6261 & 0,4077 \\
\hline & Q56 & 3,0355 & 1,4983 & 0,5286 \\
\hline & Q35 & 2,8670 & 1,5248 & 0,5352 \\
\hline & Q33 & 2,8008 & 1,4597 & 0,5819 \\
\hline & Q12 & 2,7882 & 1,5176 & 0,5919 \\
\hline & Q23 & 2,9777 & 1,4437 & 0,6314 \\
\hline & Q79 & 2,6901 & 1,4626 & 0,6807 \\
\hline \multirow[t]{8}{*}{ New variable 10} & Q34 & 2,6444 & 1,5183 & 0,7148 \\
\hline & Q78 & 2,9362 & 1,6902 & 0,7495 \\
\hline & Q41 & 2,5487 & 1,4407 & 0,8386 \\
\hline & Q45 & 2,5048 & 1,3590 & 0,9770 \\
\hline & Q11 & 2,4711 & 1,3919 & 0,9944 \\
\hline & Q58 & 2,3424 & 1,5642 & 1,1727 \\
\hline & Q53 & 2,1721 & 1,3036 & 1,2429 \\
\hline & Q52 & 2,1420 & 1,4670 & 1,4317 \\
\hline
\end{tabular}

Note: Items arranged according to degree of skewness.

From Table 6 it can be seen that the coefficients of skewness vary from $-1,7592$ to 1,4317 .

Next, new variables were formed by adding the scores of eight adjacent items together. The new variables were then arranged in terms of their degree of skewness. The descriptive statistics of the new variables are given in Table 7.

TABLE 7

MMEANS, STANDARD DEVIATIONS AND COEFICIENTS OF SKEWNESS AND KURTOSIS OF THE NEW VARIABLES

\begin{tabular}{lcccc}
\hline & Variable & $\begin{array}{c}\text { Standard } \\
\text { deviation }\end{array}$ & $\begin{array}{c}\text { Coefficient } \\
\text { of skewness }\end{array}$ & $\begin{array}{c}\text { Coefficient } \\
\text { of kurtosis }\end{array}$ \\
\hline New variable 1 & 48,892 & 4,750 & $-1,006$ & 1,605 \\
New variable 2 & 46,218 & 4,677 & $-0,421$ & 0,109 \\
New variable 3 & 44,799 & 5,102 & $-0,352$ & 0,397 \\
New variable 5 & 43,211 & 5,029 & $-0,343$ & 0,046 \\
New variable 4 & 43,495 & 4,962 & $-0,233$ & 0,072 \\
New variable 6 & 40,122 & 4,724 & $-0,065$ & $-0,019$ \\
New variable 7 & 35,300 & 4,534 & $-0,054$ & 0,189 \\
New variable 8 & 28,944 & 5,453 & 0,012 & $-0,176$ \\
New variable 9 & 23,481 & 6,441 & 0,276 & $-0,254$ \\
New variable 10 & 19,762 & 6,219 & 0,478 & 0,125 \\
\hline
\end{tabular}

Note: Standard error of coeffient of skewness $=0,06$

Standard error of coefficient of kurtosis $=0,12$
From Table 7 it can be seen that the coefficients of skewness range from $-1,006$ to 0,478 . The new variables are therefore less skew than the original items.

Next, the new variables were intercorrelated. The matrix of intercorrelations is given in Table 8 .

Table 8 shows that the highest correlations are adjacent to the principal diagonal and taper off as you move from left to right and from top to bottom. However, small departures from this trend is also visible. These gradients are typical of a simplex. Furthermore, the column totals also reveal the typical pattern of a simplex: the successive totals increase in size until a maximum is reached, and then systematically decrease in size. However, a more objective test is to inspect the inverse of the correlation matrix.

The inverse of the intercorrelation matrix was accordingly calculated and is given in Table 9.

It is evident from Table 9 that the principal diagonal is positive and the two adjacent diagonals are negative. However, the offdiagonals are not equal to zero. The intercorrelation matrix is therefore a pseudo-simplex.

From the foregoing it is clear that if continuous variables are arranged according to their degree of skewness, the correlations between the variables show gradients similar to that of a simplex. It is therefore expected that such matrices will generate factors of skewness, if factor analysed.

Objective 2: Factor structure of an intercorrelation matrix based on continuous variables, arranged in terms of degree of skewness

To determine the factor structure of an intercorrelation matrix based on continuous variables, arranged according to degree of skewness, the LCI data were used. Parcels of four adjacent items in terms of skewness, were formed. The descriptive statistics are given in Table 10.

From Table 10 it is clear that the coefficients of skewness vary from $-1,16$ to 0,77 .

Next, the new variables were intercorrelated. The matrix of intercorrelations is given in Table 11.

Although there is not a clear gradient visible in Table 11, the correlations nevertheless become smaller as you move from left to right and from top to bottom.

The eigenvalues of the unreduced intercorrelation matrix are given in Table 12.

From Table 12 it is evident that there are three eigenvalues greater than unity, suggesting three factors.

Three factors were extracted and rotated to simple structure by means of a Direct Oblimin rotation. The rotated factor matrix is given in Table 13.

From Table 13 it is clear that parcels 1, 2, 3 and 9 have high loadings on Factor III. Parcels 4 to 14 (excluding parcel 9) load on Factor I, and parcels 15 to 20 load on Factor II. Each of the factors have high loadings on parcels with fairly similar coefficients of skewness. The only exception being parcel 9. It is therefore reasonable to identify the three factors as factors of skewness.

In order to examine the contents of the three factors obtained, the items represented by the subscores were listed. The listing of the items is given in Table 14 . 
TABLE 8

MATRIX OF INTERCORRELATIONS OF THE NEW VARIABLES ARRANGED ACCORDING TO THEIR DEGREE OF SKEWNESS

\begin{tabular}{|c|c|c|c|c|c|c|c|c|c|c|c|}
\hline & New var 1 & New var 2 & New var 3 & New var 5 & New var 4 & New var 6 & New var 7 & New var 8 & New var 9 & New var 10 & Total \\
\hline New var 1 & 1,000 & 0,640 & 0,539 & 0,548 & 0,535 & 0,386 & 0,174 & $-0,152$ & $-0,157$ & $-0,303$ & 3,211 \\
\hline New var 2 & 0,640 & 1,000 & 0,606 & 0,602 & 0,600 & 0,533 & 0,224 & $-0,214$ & $-0,237$ & $-0,379$ & 3,375 \\
\hline New var 3 & 0,539 & 0,606 & 1,000 & 0,670 & 0,660 & 0,554 & 0,280 & $-0,158$ & $-0,150$ & $-0,270$ & 3,732 \\
\hline New var 5 & 0,548 & 0,602 & 0,670 & 1,000 & 0,615 & 0,565 & 0,266 & $-0,134$ & $-0,078$ & $-0,253$ & 3,801 \\
\hline New var 4 & 0,535 & 0,600 & 0,660 & 0,615 & 1,000 & 0,556 & 0,258 & $-0,210$ & $-0,193$ & $-0,332$ & 3,488 \\
\hline New var 6 & 0,386 & 0,533 & 0,554 & 0,565 & 0,556 & 1,000 & 0,351 & $-0,121$ & $-0,130$ & $-0,233$ & 3,461 \\
\hline New var 7 & 0,174 & 0,224 & 0,280 & 0,266 & 0,258 & 0,351 & 1,000 & 0,230 & 0,158 & 0,151 & 3,093 \\
\hline New var 8 & $-0,152$ & $-0,214$ & $-0,158$ & $-0,134$ & $-0,210$ & $-0,121$ & 0,230 & 1,000 & 0,444 & 0,515 & 1,201 \\
\hline New var 9 & $-0,157$ & $-0,237$ & $-0,150$ & $-0,078$ & $-0,193$ & $-0,130$ & 0,158 & 0,444 & 1,000 & 0,663 & 1,319 \\
\hline New var 10 & $-0,303$ & $-0,379$ & $-0,270$ & $-0,253$ & $-0,332$ & $-0,233$ & 0,151 & 0,515 & 0,663 & 1,000 & 0,559 \\
\hline Total & 3,211 & 3,375 & 3,732 & 3,801 & 3,488 & 3,461 & 3,093 & 1,201 & 1,319 & 0,559 & \\
\hline
\end{tabular}

TABLE 9

INVERSE OF INTERCORRELATION MATRIX

\begin{tabular}{|c|c|c|c|c|c|c|c|c|c|c|}
\hline & New var 1 & New var 2 & New var 3 & New var 5 & New var 4 & New var 6 & New var 7 & New var 8 & New var 9 & New var 10 \\
\hline New var 1 & 1,909 & $-0,783$ & $-0,230$ & $-0,322$ & $-0,260$ & 0,156 & 0,001 & $-0,045$ & $-0,050$ & 0,144 \\
\hline New var 2 & $-0,783$ & 2,390 & $-0,316$ & $-0,331$ & $-0,271$ & $-0,348$ & $-0,095$ & 0,046 & 0,099 & 0,253 \\
\hline New var 3 & $-0,230$ & $-0,316$ & 2,414 & $-0,719$ & $-0,652$ & $-0,263$ & $-0,127$ & 0,036 & 0,064 & $-0,039$ \\
\hline New var 5 & $-0,322$ & $-0,331$ & $-0,719$ & 2,333 & $-0,357$ & $-0,411$ & $-0,034$ & 0,010 & $-0,265$ & 0,135 \\
\hline New var 4 & $-0,260$ & $-0,271$ & $-0,652$ & $-0,357$ & 2,266 & $-0,349$ & $-0,133$ & 0,120 & 0,016 & 0,171 \\
\hline New var 6 & 0,156 & $-0,348$ & $-0,263$ & $-0,411$ & $-0,349$ & 1,842 & $-0,346$ & 0,030 & 0,044 & 0,060 \\
\hline New var 7 & 0,001 & $-0,095$ & $-0,127$ & $-0,034$ & $-0,133$ & $-0,346$ & 1,328 & $-0,281$ & $-0,051$ & $-0,225$ \\
\hline New var 8 & $-0,045$ & 0,046 & 0,036 & 0,010 & 0,120 & 0,030 & $-0,281$ & 1,463 & $-0,247$ & $-0,484$ \\
\hline New var 9 & $-0,050$ & 0,099 & 0,064 & $-0,265$ & 0,016 & 0,044 & $-0,051$ & $-0,247$ & 1,871 & $-1,117$ \\
\hline New var 10 & 0,144 & 0,253 & $-0,039$ & 0,135 & 0,171 & 0,060 & $-0,225$ & $-0,484$ & $-1,117$ & 2,257 \\
\hline
\end{tabular}

TABLE 10

MEANS, STANDARD DEVIATIONS AND COEFFICIENTS OF SKEWNESS AND KURTOSIS OF THE NEW VARIABLES

\begin{tabular}{lcccc}
\hline & Variable & $\begin{array}{c}\text { Standard } \\
\text { deviation }\end{array}$ & $\begin{array}{c}\text { Coefficient } \\
\text { of skewness }\end{array}$ & $\begin{array}{c}\text { Coefficient } \\
\text { of kurtosis }\end{array}$ \\
\hline New variable 2 & 24,36 & 2,61 & $-1,16$ & 2,54 \\
New variable 1 & 24,53 & 2,74 & $-0,92$ & 0,83 \\
New variable 3 & 23,73 & 2,82 & $-0,70$ & 0,86 \\
New variable 5 & 22,84 & 3,12 & $-0,54$ & 0,29 \\
New variable 10 & 21,02 & 3,14 & $-0,45$ & 0,22 \\
New variable 4 & 22,49 & 2,79 & $-0,43$ & $-0,03$ \\
New variable 7 & 21,65 & 3,05 & $-0,38$ & 0,15 \\
New variable 6 & 21,96 & 2,89 & $-0,34$ & 0,23 \\
New variable 9 & 22,19 & 2,78 & $-0,33$ & $-0,09$ \\
New variable 11 & 20,85 & 3,03 & $-0,33$ & 0,10 \\
New variable 8 & 21,85 & 2,81 & $-0,20$ & $-0,14$ \\
New variable 14 & 16,89 & 2,87 & $-0,12$ & 0,13 \\
New variable 13 & 18,41 & 2,98 & $-0,10$ & 0,01 \\
New variable 12 & 19,27 & 2,81 & 0,01 & $-0,05$ \\
New variable 15 & 15,22 & 3,04 & 0,01 & 0,16 \\
New variable 16 & 13,72 & 3,72 & 0,04 & $-0,48$ \\
New variable 17 & 12,22 & 3,94 & 0,21 & $-0,48$ \\
New variable 19 & 10,63 & 3,84 & 0,36 & $-0,19$ \\
New variable 18 & 11,26 & 3,57 & 0,37 & 0,03 \\
New variable 20 & 9,13 & 3,65 & 0,77 & 0,38 \\
\hline
\end{tabular}

Note: Standard error of coefficient of skewness $=0,06$

Standard error of coefficient of kurtosis $=0,12$
From Table 14 it is clear that 24 of the 40 items loading on Factor $\mathrm{I}$, are classified as Autonomy according to the scoring key. Eleven of the items are classified as Internal Control and five are classified as External Control.

As far as Factor II is concerned 23 of the 24 items are classified as External Control and one as Autonomy.

Fifteen of the 16 items loading on Factor III are classified as Internal Control and one as Autonomy.

From the foregoing it is clear that 24 of the 26 Autonomy items (according to the key) were correctly classified, 23 of the 28 External Control items were correctly classified, and 15 of the 26 Internal Control items were correctly classified. Eleven of the Internal Control items were misclassified as Autonomy. This is also evident in the matrix of intercorrelations of the factors (see Table 13): Factor I (Autonomy) correlates 0,496 with Factor III (Internal Control).

According to Table 10 the coefficients of skewness of the parcels loading on the first factor, range from $-1,16$ to $-0,70$, and those loading on the third factor, range from $-0,54$ to 0,01 . The coefficients of skewness of the parcels loading on the second factor range from 0,01 to 0,77 . The coefficients of skewness of the parcels loading on Factors I and III are thus essentially negative, whereas those of Factor II are positive. 
TABLE 11

MATRIX OF INTERCORRELATIONS OF THE NEW VARIABLES ARRANGED ACCORDING TO THEIR DEGREE OF SKEWNESS

\begin{tabular}{|c|c|c|c|c|c|c|c|c|c|c|}
\hline Variables & New var 2 & New var 1 & New var 3 & New var 5 & New var 10 & New var 4 & New var 7 & New var 6 & New var 9 & New var 11 \\
\hline New var 2 & 1,000 & 0,577 & 0,546 & 0,390 & 0,330 & 0,383 & 0,326 & 0,392 & 0,500 & 0,360 \\
\hline New var 1 & 0,577 & 1,000 & 0,538 & 0,428 & 0,365 & 0,428 & 0,401 & 0,416 & 0,476 & 0,394 \\
\hline New var 3 & 0,546 & 0,538 & 1,000 & 0,397 & 0,363 & 0,394 & 0,372 & 0,397 & 0,464 & 0,386 \\
\hline New var 5 & 0,390 & 0,428 & 0,397 & 1,000 & 0,508 & 0,465 & 0,454 & 0,442 & 0,469 & 0,520 \\
\hline New var 10 & 0,330 & 0,365 & 0,363 & 0,508 & 1,000 & 0,435 & 0,458 & 0,471 & 0,443 & 0,526 \\
\hline New var 4 & 0,383 & 0,428 & 0,394 & 0,465 & 0,435 & 1,000 & 0,453 & 0,462 & 0,454 & 0,563 \\
\hline New var 7 & 0,326 & 0,401 & 0,372 & 0,454 & 0,458 & 0,453 & 1,000 & 0,491 & 0,442 & 0,545 \\
\hline New var 6 & 0,392 & 0,416 & 0,397 & 0,442 & 0,471 & 0,462 & 0,491 & 1,000 & 0,485 & 0,501 \\
\hline New var 9 & 0,500 & 0,476 & 0,464 & 0,469 & 0,443 & 0,454 & 0,442 & 0,485 & 1,000 & 0,486 \\
\hline New var 11 & 0,360 & 0,394 & 0,386 & 0,520 & 0,526 & 0,563 & 0,545 & 0,501 & 0,486 & 1,000 \\
\hline New var 8 & 0,423 & 0,461 & 0,427 & 0,461 & 0,392 & 0,445 & 0,429 & 0,493 & 0,480 & 0,488 \\
\hline New var 14 & 0,001 & 0,026 & $-0,055$ & 0,095 & 0,140 & 0,108 & 0,115 & 0,113 & 0,046 & 0,143 \\
\hline New var 13 & 0,234 & 0,212 & 0,224 & 0,247 & 0,276 & 0,296 & 0,257 & 0,279 & 0,225 & 0,362 \\
\hline New var 12 & 0,174 & 0,162 & 0,209 & 0,284 & 0,286 & 0,264 & 0,256 & 0,190 & 0,230 & 0,306 \\
\hline New var 15 & $-0,080$ & $-0,122$ & $-0,137$ & $-0,077$ & 0,001 & $-0,084$ & $-0,095$ & $-0,063$ & $-0,111$ & $-0,075$ \\
\hline New var 16 & $-0,077$ & $-0,149$ & $-0,192$ & $-0,146$ & $-0,090$ & $-0,149$ & $-0,202$ & $-0,133$ & $-0,164$ & $-0,172$ \\
\hline New var 17 & $-0,038$ & $-0,116$ & $-0,173$ & $-0,040$ & 0,048 & $-0,113$ & $-0,090$ & $-0,055$ & $-0,066$ & $-0,034$ \\
\hline New var 19 & $-0,160$ & $-0,247$ & $-0,284$ & $-0,206$ & $-0,109$ & $-0,216$ & $-0,230$ & $-0,197$ & $-0,193$ & $-0,159$ \\
\hline New var 18 & $-0,130$ & $-0,201$ & $-0,230$ & $-0,208$ & $-0,091$ & $-0,168$ & $-0,163$ & $-0,145$ & $-0,140$ & $-0,119$ \\
\hline New var 20 & $-0,216$ & $-0,269$ & $-0,316$ & $-0,190$ & $-0,139$ & $-0,236$ & $-0,249$ & $-0,167$ & $-0,292$ & $-0,216$ \\
\hline \multirow[t]{23}{*}{ Total } & 4,936 & 4,781 & 4,328 & 5,294 & 5,612 & 5,186 & 4,969 & 5,373 & 5,235 & 5,804 \\
\hline & New var 8 & New var 14 & New var 13 & New var 12 & New var 15 & New var 16 & New var 17 & New var 19 & New var 18 & New var 20 \\
\hline & 0,423 & 0,001 & 0,234 & 0,174 & $-0,080$ & $-0,077$ & $-0,038$ & $-0,160$ & $-0,130$ & $-0,216$ \\
\hline & 0,461 & 0,026 & 0,212 & 0,162 & $-0,122$ & $-0,149$ & $-0,116$ & $-0,247$ & $-0,201$ & $-0,269$ \\
\hline & 0,427 & $-0,055$ & 0,224 & 0,209 & $-0,137$ & $-0,192$ & $-0,173$ & $-0,284$ & $-0,230$ & $-0,316$ \\
\hline & 0,461 & 0,095 & 0,247 & 0,284 & $-0,077$ & $-0,146$ & $-0,040$ & $-0,206$ & $-0,208$ & $-0,190$ \\
\hline & 0,392 & 0,140 & 0,276 & 0,286 & 0,001 & $-0,090$ & 0,048 & $-0,109$ & $-0,091$ & $-0,139$ \\
\hline & 0,445 & 0,108 & 0,296 & 0,264 & $-0,084$ & $-0,149$ & $-0,113$ & $-0,216$ & $-0,168$ & $-0,236$ \\
\hline & 0,429 & 0,115 & 0,257 & 0,256 & $-0,095$ & $-0,202$ & $-0,090$ & $-0,230$ & $-0,163$ & $-0,249$ \\
\hline & 0,493 & 0,113 & 0,279 & 0,190 & $-0,063$ & $-0,133$ & $-0,055$ & $-0,197$ & $-0,145$ & $-0,167$ \\
\hline & 0,480 & 0,046 & 0,225 & 0,230 & $-0,111$ & $-0,164$ & $-0,066$ & $-0,193$ & $-0,140$ & $-0,292$ \\
\hline & 0,488 & 0,143 & 0,362 & 0,306 & $-0,075$ & $-0,172$ & $-0,034$ & $-0,159$ & $-0,119$ & $-0,216$ \\
\hline & 1,000 & 0,045 & 0,249 & 0,206 & $-0,118$ & $-0,142$ & $-0,119$ & $-0,228$ & $-0,199$ & $-0,226$ \\
\hline & 0,045 & 1,000 & 0,202 & 0,170 & 0,254 & 0,225 & 0,194 & 0,188 & 0,130 & 0,207 \\
\hline & 0,249 & 0,202 & 1,000 & 0,195 & 0,066 & 0,042 & 0,081 & 0,014 & 0,014 & $-0,013$ \\
\hline & 0,206 & 0,170 & 0,195 & 1,000 & 0,004 & $-0,047$ & $-0,071$ & $-0,114$ & $-0,147$ & $-0,133$ \\
\hline & $-0,118$ & 0,254 & 0,066 & 0,004 & 1,000 & 0,291 & 0,266 & 0,316 & 0,252 & 0,251 \\
\hline & $-0,142$ & 0,225 & 0,042 & $-0,047$ & 0,291 & 1,000 & 0,374 & 0,375 & 0,316 & 0,415 \\
\hline & $-0,119$ & 0,194 & 0,081 & $-0,071$ & 0,266 & 0,374 & 1,000 & 0,533 & 0,470 & 0,445 \\
\hline & $-0,228$ & 0,188 & 0,014 & $-0,114$ & 0,316 & 0,375 & 0,533 & 1,000 & 0,555 & 0,381 \\
\hline & $-0,199$ & 0,130 & 0,014 & $-0,147$ & 0,252 & 0,316 & 0,470 & 0,555 & 1,000 & 0,346 \\
\hline & $-0,226$ & 0,207 & $-0,013$ & $-0,133$ & 0,251 & 0,415 & 0,445 & 0,381 & 0,346 & 1,000 \\
\hline & 4,965 & 3,348 & 4,462 & 3,423 & 1,737 & 1,375 & 2,494 & 1,017 & 1,143 & 0,382 \\
\hline
\end{tabular}

TABLE 12

EIGENVALUES OF INTERCORRELATION MATRIX

\begin{tabular}{cc}
\hline Root & Eigenvalue \\
\hline 1 & $\underline{6,251}$ \\
2 & $\underline{2,765}$ \\
3 & $\underline{1,202}$ \\
4 & 0,949 \\
5 & 0,807 \\
6 & 0,793 \\
7 & 0,774 \\
8 & 0,686 \\
9 & 0,611 \\
10 & 0,589 \\
11 & 0,552 \\
12 & 0,544 \\
13 & 0,513 \\
14 & 0,487 \\
15 & 0,456 \\
16 & 0,442 \\
17 & 0,435 \\
18 & 0,401 \\
19 & 0,388 \\
20 & 0,376 \\
\hline Trace & 20,000 \\
\hline
\end{tabular}


TABLE 13

ROTATED FACTOR MATRIX (DIRECT OBLIMIN)

\begin{tabular}{|c|c|c|c|c|c|}
\hline VARIABLES & K & FACTOR I & FACTOR II & FACTOR III & $\mathbf{h}_{\mathrm{i}}^{2}$ \\
\hline $\begin{array}{l}\text { New var 11: Items } 5,14, \\
44 \text { and } 74\end{array}$ & 4 & 0,737 & $-0,077$ & 0,064 & 0,611 \\
\hline $\begin{array}{l}\text { New var 10: Items 25, 29, } \\
30 \text { and } 32\end{array}$ & 4 & 0,616 & 0,026 & 0,125 & 0,468 \\
\hline $\begin{array}{l}\text { New var } 7 \text { : Items } 2,40, \\
70 \text { and } 73\end{array}$ & 4 & 0,599 & $-0,155$ & 0,091 & 0,470 \\
\hline $\begin{array}{l}\text { New var } 4 \text { : Items } 8,13, \\
28 \text { and } 62\end{array}$ & 4 & 0,557 & $-0,116$ & 0,170 & 0,472 \\
\hline $\begin{array}{l}\text { New var 5: Items 16, 22, } \\
66 \text { and } 67\end{array}$ & 4 & 0,548 & $-0,085$ & 0,195 & 0,471 \\
\hline $\begin{array}{l}\text { New var } 6 \text { : Items } 24,48, \\
54 \text { and } 69\end{array}$ & 4 & 0,519 & $-0,046$ & 0,237 & 0,461 \\
\hline $\begin{array}{l}\text { New var 12: Items 1, 9, } \\
26 \text { and } 39\end{array}$ & 4 & 0,430 & $-0,088$ & $-0,065$ & 0,172 \\
\hline $\begin{array}{l}\text { New var 13: Items } 15,47, \\
50 \text { and } 64\end{array}$ & 4 & 0,416 & 0,149 & 0,082 & 0,217 \\
\hline $\begin{array}{l}\text { New var 8: Items } 6,46, \\
68 \text { and } 76\end{array}$ & 4 & 0,406 & $-0,103$ & 0,326 & 0,444 \\
\hline $\begin{array}{l}\text { New var } 14 \text { : Items } 3,51, \\
71 \text { and } 77\end{array}$ & 4 & 0,392 & 0,310 & $-0,164$ & 0,226 \\
\hline $\begin{array}{l}\text { New var 17: Items } 35,36 \text {, } \\
43 \text { and } 56\end{array}$ & 4 & 0,028 & 0,747 & 0,110 & 0,514 \\
\hline $\begin{array}{l}\text { New var 19: Items } 34,41 \\
45 \text { and } 78\end{array}$ & 4 & $-0,100$ & 0,726 & 0,017 & 0,540 \\
\hline $\begin{array}{l}\text { New var 18: Items } 12,23 \text {, } \\
33 \text { and } 79\end{array}$ & 4 & $-0,107$ & 0,643 & 0,057 & 0,410 \\
\hline $\begin{array}{l}\text { New var 16: Items } 4,20 \text {, } \\
21 \text { and } 57\end{array}$ & 4 & $-0,066$ & 0,570 & 0,025 & 0,325 \\
\hline $\begin{array}{l}\text { New var 20: Items } 11,52 \text {, } \\
53 \text { and } 58\end{array}$ & 4 & $-0,059$ & 0,551 & $-0,138$ & 0,391 \\
\hline $\begin{array}{l}\text { New var 15: Items } 38,65 \text {, } \\
72 \text { and } 80\end{array}$ & 4 & 0,086 & 0,422 & $-0,083$ & 0,203 \\
\hline $\begin{array}{l}\text { New var 2: Items 10, 18, } \\
37 \text { and } 49\end{array}$ & 4 & 0,029 & 0,107 & 0,795 & 0,809 \\
\hline $\begin{array}{l}\text { New var 1: Items 19, 42, } \\
60 \text { and } 61\end{array}$ & 4 & 0,150 & $-0,039$ & 0,638 & 0,544 \\
\hline $\begin{array}{l}\text { New var 3: Items 31, 59, } \\
63 \text { and } 75\end{array}$ & 4 & 0,136 & $-0,124$ & 0,591 & 0,515 \\
\hline $\begin{array}{l}\text { New var 9: Items } 7,17, \\
27 \text { and } 55\end{array}$ & 4 & 0,361 & $-0,046$ & 0,438 & 0,498 \\
\hline Number of items per factor & & 40 & 24 & 16 & \\
\hline
\end{tabular}

INTERCORRELATIONS OF FACTORS

\begin{tabular}{lccc}
\hline VARIABLES & FACTOR I & FACTOR II & FACTOR III \\
\hline FACTOR I & 1,000 & $-0,086$ & $\mathbf{0 , 4 9 6}$ \\
FACTOR II & $-0,086$ & 1,000 & $-0,339$ \\
FACTOR III & $\mathbf{0 , 4 9 6}$ & $-\mathbf{0 , 3 3 9}$ & 1,000 \\
\hline
\end{tabular}

Note: Factor I = Autonomy

Factor II = External Control

Factor III = Internal Control
TABLE 14

ITEMS CORRECTLY AND INCORRECTLY CLASSIFIED ACCORDING TO CONTENT

\begin{tabular}{|c|c|c|c|c|c|c|c|}
\hline \multirow[b]{2}{*}{ Q1 } & \multicolumn{2}{|c|}{ AUTONOMY } & \multicolumn{2}{|c|}{ EXTERNAL CONTROL } & \multirow{2}{*}{$\begin{array}{c}\text { INTERNAL } \\
\text { Q7 }\end{array}$} & \multicolumn{2}{|c|}{ CONTROL } \\
\hline & A & & Q4 & E & & I & \\
\hline Q2 & A & & Q11 & $\mathrm{E}$ & Q10 & I & \\
\hline Q3 & A & & Q12 & $\mathrm{E}$ & Q17 & A & * \\
\hline Q5 & A & & Q20 & $\mathrm{E}$ & Q18 & I & \\
\hline Q6 & I & * & Q21 & $\mathrm{E}$ & Q19 & I & \\
\hline Q8 & I & * & Q23 & $\mathrm{E}$ & Q27 & I & \\
\hline Q9 & $\mathrm{E}$ & ** & Q33 & $\mathrm{E}$ & Q31 & I & \\
\hline Q13 & A & & Q34 & $\mathrm{E}$ & Q37 & I & \\
\hline Q14 & A & & Q35 & $\mathrm{E}$ & Q42 & I & \\
\hline Q15 & A & & Q36 & $\mathrm{E}$ & Q49 & I & \\
\hline Q16 & I & * & Q38 & $\mathrm{E}$ & Q55 & I & \\
\hline Q22 & A & & Q41 & $\mathrm{E}$ & Q59 & I & \\
\hline Q24 & A & & Q43 & $\mathrm{E}$ & Q60 & I & \\
\hline Q25 & I & * & Q45 & $\mathrm{E}$ & Q61 & I & \\
\hline Q26 & I & * & Q52 & $\mathrm{E}$ & Q63 & I & \\
\hline Q28 & A & & Q53 & $\mathrm{E}$ & Q75 & I & \\
\hline Q29 & $\mathrm{A}$ & & Q56 & $\mathrm{E}$ & & & \\
\hline Q30 & A & & Q57 & $\mathrm{E}$ & & & \\
\hline Q32 & I & * & Q58 & $\mathrm{E}$ & & & \\
\hline Q39 & A & & Q65 & $\mathrm{E}$ & & & \\
\hline Q40 & I & * & Q72 & $\mathrm{A} \quad *$ & & & \\
\hline Q44 & A & & Q78 & $\mathrm{E}$ & & & \\
\hline Q46 & $\mathrm{A}$ & & Q79 & $\mathrm{E}$ & & & \\
\hline Q47 & $\mathrm{E}$ & $* *$ & Q80 & $\mathrm{E}$ & & & \\
\hline Q48 & I & * & & & & & \\
\hline Q50 & $\mathrm{E}$ & ** & & & & & \\
\hline Q51 & $\mathrm{E}$ & ** & & & & & \\
\hline Q54 & I & * & & & & & \\
\hline Q62 & A & & & & & & \\
\hline Q64 & A & & & & & & \\
\hline Q66 & $\mathrm{A}$ & & & & & & \\
\hline Q67 & A & & & & & & \\
\hline Q68 & A & & & & & & \\
\hline Q69 & I & * & & & & & \\
\hline Q70 & A & & & & & & \\
\hline Q71 & $\mathrm{A}$ & & & & & & \\
\hline Q73 & A & & & & & & \\
\hline Q74 & A & & & & & & \\
\hline Q76 & I & * & & & & & \\
\hline Q77 & $\mathrm{E}$ & $* *$ & & & & & \\
\hline
\end{tabular}

Note: A = Autonomy; E = External Control; I = Internal Control

Items marked with * and ** have been misclassified according to the scoring key 
TABLE 15

MATRIX OF INTERCORRELATIONS OF THE SUBTESTS OF THE LOCUS OF CONTROL INVENTORY (1995)

\begin{tabular}{|c|c|c|c|c|c|c|c|c|}
\hline Variable & Subtest 1 & Subtest 2 & Subtest 3 & Subtest 4 & Subtest 5 & Subtest 6 & Subtest 7 & Subtest 8 \\
\hline Subtest 1 & 1,0000 & & & & & & & \\
\hline Subtest 2 & $-0,0660$ & 1,0000 & & & & & & \\
\hline Subtest 3 & 0,3673 & $-0,1870$ & 1,0000 & & & & & \\
\hline Subtest 4 & $-0,1112$ & 0,3609 & $-0,2250$ & 1,0000 & & & & \\
\hline Subtest 5 & $-0,1193$ & 0,4261 & $-0,1823$ & 0,3997 & 1,0000 & & & \\
\hline Subtest 6 & 0,5352 & $-0,1262$ & 0,4588 & $-0,1844$ & $-0,1430$ & 1,0000 & & \\
\hline Subtest 7 & 0,4443 & $-0,2841$ & 0,2299 & $-0,3492$ & $-0,3382$ & 0,2890 & 1,0000 & \\
\hline Subtest 8 & 0,2911 & $-0,1325$ & 0,3450 & $-0,1474$ & $-0,1492$ & 0,3189 & 0,2669 & 1,0000 \\
\hline Subtest 9 & 0,5430 & $-0,1719$ & 0,3074 & $-0,1914$ & $-0,2084$ & 0,3998 & 0,4747 & 0,3398 \\
\hline Subtest 10 & 0,3192 & 0,0411 & 0,3547 & $-0,0128$ & 0,0477 & 0,3824 & 0,0900 & 0,1494 \\
\hline Subtest 11 & 0,3171 & $-0,0056$ & 0,4365 & $-0,0927$ & 0,0012 & 0,3209 & 0,1342 & 0,1703 \\
\hline Subtest 12 & 0,3335 & $-0,0827$ & 0,4752 & $-0,0827$ & $-0,0803$ & 0,3639 & 0,1527 & 0,3046 \\
\hline Subtest 13 & $-0,1734$ & 0,1992 & $-0,0888$ & 0,2190 & 0,2050 & $-0,1807$ & $-0,2647$ & 0,0033 \\
\hline Subtest 14 & $-0,2024$ & 0,3260 & $-0,1508$ & 0,3008 & 0,3533 & $-0,2132$ & $-0,3866$ & $-0,1948$ \\
\hline Subtest 15 & $-0,1889$ & 0,1709 & $-0,1242$ & 0,2012 & 0,3143 & $-0,1844$ & $-0,2833$ & $-0,2028$ \\
\hline Subtest 16 & 0,0403 & 0,1888 & 0,1442 & 0,1621 & 0,3073 & 0,0453 & $-0,1050$ & 0,0330 \\
\hline Subtest 17 & 0,5388 & $-0,1952$ & 0,4480 & $-0,2378$ & $-0,1795$ & 0,4685 & $-0,4335$ & 0,3277 \\
\hline Subtest 9 & Subtest 10 & Subtest 11 & Subtest 12 & Subtest 13 & Subtest 14 & Subtest 15 & Subtest 16 & Subtest 17 \\
\hline \multicolumn{9}{|l|}{1,0000} \\
\hline 0,2278 & 1,0000 & & & & & & & \\
\hline 0,2094 & 0,3938 & 1,0000 & & & & & & \\
\hline 0,2518 & 0,2506 & 0,2515 & 1,0000 & & & & & \\
\hline$-0,1470$ & $-0,0074$ & $-0,0225$ & $-0,0553$ & 1,0000 & & & & \\
\hline$-0,2475$ & $-0,0021$ & $-0,0424$ & $-0,0922$ & 0,2427 & 1,0000 & & & \\
\hline$-0,2405$ & $-0,0590$ & $-0,0711$ & $-0,1527$ & 0,1579 & 0,2135 & 1,0000 & & \\
\hline$-0,0269$ & 0,1719 & 0,1824 & 0,1467 & 0,1067 & 0,1589 & 0,1321 & 1,0000 & \\
\hline 0,5171 & 0,3308 & 0,3401 & 0,3231 & $-0,2012$ & $-0,2200$ & $-0,2156$ & 0,0121 & 1,0000 \\
\hline
\end{tabular}

TABLE 16

EIGENVALUES OF UNREDUCED INTERCORRELATION MATRIX (17 X 17)

\begin{tabular}{cc}
\hline Root & Eigenvalue \\
\hline 1 & 4,727540 \\
3 & 2,373090 \\
4 & 1,103630 \\
5 & 1,002740 \\
6 & 0,861917 \\
7 & 0,837644 \\
8 & 0,773758 \\
9 & 0,695669 \\
10 & 0,650908 \\
11 & 0,620371 \\
12 & 0,606981 \\
13 & 0,532800 \\
14 & 0,521134 \\
15 & 0,466443 \\
16 & 0,450356 \\
17 & 0,411529 \\
Trace & 0,363493 \\
\hline
\end{tabular}

Objective 3: Overcoming the effects of differential skewness of test items in scale construction

As the procedure that was followed is fully described in the method section, only the essential results are given here.

The items of the LCI were intercorrelated, and the eigenvalues of the intercorrelation matrix were calculated. Nineteen of the eigenvalues were greater than unity, accordingly 19 factors were extracted and rotated to simple structure by means of a Varimax rotation.

Two of the factors had one loading each and were discarded. Next 17 subscores were formed by adding all the items with substantial loadings on a factor, together. The 17 subscores were then intercorrelated. The matrix of intercorrelations is given in Table 15

From Table 15 it is clear that the correlations of the subscores with one another vary from moderate to low and from positive to negative, suggesting more than one factor.

Next, the eigenvalues of the intercorrelation matrix were calculated. The obtained eigenvalues are given in Table 16.

Four of the eigenvalues were greater than unity, suggesting four factors (Kaiser, 1961).

Accordingly four factors were extracted and rotated to simple structure by means of a Direct Oblimin rotation. The rotated factor matrix is given in Table 17.

From an inspection of Table 17 it is clear that the first three factors are well determined with four or more high loadings. However, the fourth factor had only one high loading. A threefactor-solution was therefore tried. The obtained factor matrix is given in Table 18.

From Table 18 it is clear that all three factors are well determined with four or more high loadings. From the intercorrelations of the factors it is clear that External Control and Internal Control are essentially uncorrelated. External Control is moderately negatively correlated with Autonomy, and Internal Control is moderately positively correlated with Autonomy. 
TABLE 17

ROTATED FACTOR MARIX (DIRECT OBLIMIN)

\begin{tabular}{|c|c|c|c|c|c|c|}
\hline VARIABLES & K & FACTOR 1 & FACTOR 2 & FACTOR 3 & FACTOR 4 & $\mathbf{h}_{\mathbf{j}}^{2}$ \\
\hline Subtest 1: Items $2,3,5,14,15,22,24,28,29,62,64,67$ and 70 & 13 & $\underline{0,738}$ & 0,131 & $+0,192$ & 0,016 & 0,634 \\
\hline Subtest 2: Items $12,34,35,36,41$ and 79 & 6 & 0,081 & $\underline{0,627}$ & $-0,039$ & $-0,050$ & 0,365 \\
\hline Subtest 3: Items $10,42,49,61,63$ and 75 & 6 & $-0,090$ & $-0,275$ & $+\underline{0,694}$ & 0,244 & 0,656 \\
\hline Subtest 4 : Items $20,43,52,53,56$ and 78 & 6 & 0,027 & $\underline{0,607}$ & $-0,123$ & 0,024 & 0,360 \\
\hline Subtest 5: Items $9,51,57,58,65,77$ and 80 & 7 & 0,022 & 0,698 & $+0,050$ & $-0,080$ & 0,499 \\
\hline Subtest 6: Items $6,7,16,25,37,59$ and 69 & 7 & 0,362 & $-0,080$ & $+\underline{0,403}$ & 0,067 & 0,464 \\
\hline Subtest $7:$ Items $1,17,39,44,71$ and 72 & 6 & $\underline{0,546}$ & 0,296 & $-0,070$ & 0,020 & 0,504 \\
\hline Subtest 8: Items 8,40 and 54 & 3 & 0,228 & $-0,040$ & $+0,040$ & $\underline{0,516}$ & 0,405 \\
\hline Subtest 9: Items $30,46,73$ and 74 & 4 & 0,669 & $-0,001$ & $+0,004$ & 0,155 & 0,521 \\
\hline Subtest 10: Items 26, 27, 31 and 32 & 4 & 0,155 & 0,108 & $+\underline{0,537}$ & $-0,060$ & 0,357 \\
\hline Subtest 11: Items 18 and 19 & 2 & 0,059 & $-0,010$ & $+\underline{0,595}$ & $-0,050$ & 0,368 \\
\hline Subtest 12: Items $48,55,60$ and 76 & 4 & 0,073 & $-0,040$ & $+\underline{0,374}$ & 0,308 & 0,346 \\
\hline Subtest 13: Items 21,23 and 33 & 3 & $-0,185$ & $\underline{0,315}$ & $-0,045$ & 0,201 & 0,191 \\
\hline Subtest 14: Items 38 and 45 & 2 & $-0,194$ & $\underline{0,442}$ & $+0,050$ & $-0,040$ & 0,308 \\
\hline Subtest 15: Items 4 and 11 & 2 & $-0,203$ & $\underline{0,262}$ & $+0,050$ & $-0,130$ & 0,183 \\
\hline Subtest 16: Items 47 and 50 & 2 & $-0,050$ & $\underline{0,331}$ & $+0,295$ & 0,054 & 0,211 \\
\hline Subtest 17: Items 13,66 and 68 & 3 & $\underline{0,494}$ & $-0,109$ & $+0,310$ & 0,045 & 0,532 \\
\hline Number of items per factor & & 26 & 28 & 23 & 3 & \\
\hline
\end{tabular}

Note: Factor 3 has been reflected

TABLE 18

ROTATED FACTOR MATRIX (DIRECT OBLIMIN)

\begin{tabular}{|c|c|c|c|c|c|}
\hline VARIABLES & K & FACTOR I & FACTOR II & FACTOR III & $\mathbf{h}_{\mathrm{j}}^{2}$ \\
\hline $\begin{array}{l}\text { Subtest } 1 \text { : Items } 2,3,5 \text {, } \\
14,15,22,24,28,29 \\
62,64,67 \text { en } 70\end{array}$ & 13 & 0,146 & 0,160 & $\underline{0,754}$ & 0,634 \\
\hline $\begin{array}{l}\text { Subtest } 2 \text { : Items } 12,34 \text {, } \\
35,36,41 \text { en } 79\end{array}$ & 6 & $\underline{0,630}$ & $-0,083$ & 0,082 & 0,366 \\
\hline $\begin{array}{l}\text { Subtest } 3 \text { : Items } 10,42 \text {, } \\
49,61,63 \text { en } 75\end{array}$ & 6 & $-0,266$ & $\underline{0,828}$ & $-0,105$ & 0,678 \\
\hline $\begin{array}{l}\text { Subtest } 4 \text { : Items } 20,43 \text {, } \\
52,53,56 \text { en } 78\end{array}$ & 6 & $\underline{0,579}$ & $-0,119$ & 0,016 & 0,343 \\
\hline $\begin{array}{l}\text { Subtest 5: Items } 9,51 \text {, } \\
57,58,65,77 \text { en } 80\end{array}$ & 7 & $\underline{0,717}$ & $-0,017$ & 0,024 & 0,502 \\
\hline $\begin{array}{l}\text { Subtest } 6 \text { : Items } 6,7 \text {, } \\
16,25,37,59 \text { en } 69\end{array}$ & 7 & $-0,052$ & $\underline{0,411}$ & 0,374 & 0,462 \\
\hline $\begin{array}{l}\text { Subtest } 7 \text { : Items } 1,17 \text {, } \\
39,44,71 \text { en } 72\end{array}$ & 6 & 0,304 & 0,070 & $\underline{0,557}$ & 0,506 \\
\hline $\begin{array}{l}\text { Subtest 8: Items } 8,40 \\
\text { en } 54\end{array}$ & 3 & $-0,135$ & $\underline{0,283}$ & 0,211 & 0,219 \\
\hline $\begin{array}{l}\text { Subtest 9: Items } 30,46 \text {, } \\
73 \text { en } 74\end{array}$ & 4 & $-0,037$ & 0,065 & $\underline{0,665}$ & 0,505 \\
\hline $\begin{array}{l}\text { Subtest 10: Items 26, } \\
27,31 \text { en } 32\end{array}$ & 4 & 0,169 & $\underline{0,464}$ & 0,173 & 0,318 \\
\hline $\begin{array}{l}\text { Subtest 11: Items } 18 \\
\text { en } 19\end{array}$ & 2 & 0,056 & $\underline{0,529}$ & 0,083 & 0,324 \\
\hline $\begin{array}{l}\text { Subtest 12: Items } 48 \text {, } \\
55,60 \text { en } 76\end{array}$ & 4 & $-0,064$ & $\underline{0,514}$ & 0,074 & 0,312 \\
\hline $\begin{array}{l}\text { Subtest 13: Items } 21 \text {, } \\
23 \text { en } 33\end{array}$ & 3 & $\underline{0,262}$ & 0,057 & $-0,193$ & 0,139 \\
\hline $\begin{array}{l}\text { Subtest 14: Items } 38 \\
\text { en } 45\end{array}$ & 2 & $\underline{0,451}$ & 0,027 & $-0,198$ & 0,309 \\
\hline $\begin{array}{l}\text { Subtest 15: Items } 4 \\
\text { en } 11\end{array}$ & 2 & $\underline{0,291}$ & $-0,018$ & $-0,203$ & 0,176 \\
\hline $\begin{array}{l}\text { Subtest 16: Items } 47 \\
\text { en } 50\end{array}$ & 2 & $\underline{0,346}$ & 0,307 & $-0,048$ & 0,213 \\
\hline $\begin{array}{l}\text { Subtest 17: Items } 13 \text {, } \\
66 \text { en } 68\end{array}$ & 3 & $-0,087$ & 0,306 & $\underline{0,507}$ & 0,530 \\
\hline $\begin{array}{l}\text { Number of items per } \\
\text { factor }\end{array}$ & & 28 & 26 & 26 & 80 \\
\hline
\end{tabular}

INTERCORRELATIONS OF FACTORS

\begin{tabular}{lccc}
\hline VARIABLES & FACTOR I & FACTOR II & FACTOR III \\
\hline FACTOR I & 1,000 & & \\
FACTOR II & $-0,018$ & 1,000 & \\
FACTOR III & $\underline{-0,393}$ & $\underline{0,438}$ & 1,000 \\
\hline
\end{tabular}

Note: $\mathrm{N}=1662$

Factor I = External Control

Factor II = Internal Control

Factor III = Autonomy

Next, separate scales were formed, corresponding to each of the factors, and subjected to item analysis.

The item statistics in respect of Scale I (External Control) are given in Table 19.

From Table 19 it is clear that the item-total correlations range from 0,341 to 0,611 , with a mean of 0,459 and a standard deviation of 0,080 . The scale is therefore internally highly consistent. Items 23, 33 and 50 were rejected, because their indices of reliability were too low. The reliability of the scale according to Cronbach's coefficient alpha is 0,841 .

The item statistics in respect of Scale II (Internal Control) are given in Table 20 .

According to Table 20 the item-total correlations range from 0,301 to 0,585 , with a mean of 0,455 and a standard deviation of 0,069 . The scale is therefore internally highly consistent. No items were rejected. The reliability of the scale according to Cronbach's coefficient alpha is 0,832 .

The item statistics in respect of Scale III (Autonomy) are given in Table 21.

From Table 21 it is clear that the item-total correlations range from 0,370 to 0,575 , with a mean of 0,488 and a standard deviation of 0,074 . Therefore, the scale is internally highly consistent. No items were rejected. The reliability of the scale according to Cronbach's coefficient alpha is 0,866 . 
TABLE 19

ITEM STATISTICS IN RESPECT OF SCALE I OF THE LCI: EXTERNAL CONTROL

\begin{tabular}{|c|c|c|c|c|c|c|}
\hline & DESCRIPTION OF ITEM & $\mathbf{N}$ & $\begin{array}{l}\text { MEAN OF } \\
\text { ITEM } \\
\left(\overline{\mathrm{X}}_{\mathrm{g}}\right)\end{array}$ & $\begin{array}{l}\text { STANDARD } \\
\text { DEVIATION } \\
\text { OF ITEM } \\
\left(s_{\mathrm{g}}\right)\end{array}$ & $\begin{array}{c}\text { ITEM-TEST } \\
\text { CORRELATION } \\
\left(\mathbf{r}_{\mathrm{gx}}\right)\end{array}$ & $\begin{array}{c}\text { INDEX OF } \\
\text { RELIABILITY } \\
\text { OF ITEM } \\
\left(\mathrm{r}_{\mathrm{gx}} s_{\mathrm{g}}\right)\end{array}$ \\
\hline Q4 & $\begin{array}{l}\text { Convinced that a person without money will get nowhere, no matter how } \\
\text { hard he/she works }\end{array}$ & 1662 & 3,620 & 1,835 & 0,341 & 0,625 \\
\hline Q9 & People obtain good positions simply because they know the right people & 1662 & 5,039 & 1,291 & 0,392 & 0,506 \\
\hline Q11 & $\begin{array}{l}\text { Convinced that if once he/she has failed in something it is virtually } \\
\text { impossible to achieve in it again }\end{array}$ & 1662 & 2,471 & 1,392 & 0,379 & 0,528 \\
\hline Q12 & Convinced that he/she is subject to the whims of fate & 1662 & 2,788 & 1,518 & 0,573 & 0,869 \\
\hline Q20 & Failed because other people interfered in his/her business & 1662 & 3,397 & 1,367 & 0,409 & 0,560 \\
\hline Q21 & $\begin{array}{l}\text { Dependent on the advice and cues of others in order to produce } \\
\text { quality work }\end{array}$ & 1662 & 3,426 & 1,325 & 0,398 & 0,527 \\
\hline Q23 & Will readily support a group decision even if he/she disagrees with it & 1662 & 2,978 & 1,444 & $* * * *$ & $* * * *$ \\
\hline Q33 & $\begin{array}{l}\text { Will readily accept responsibility for errors in work situation even if } \\
\text { he/she is innocent }\end{array}$ & 1662 & 2,801 & 1,460 & $* * * *$ & $* * * *$ \\
\hline Q34 & Lady Luck plays an important role in his/her life & 1662 & 2,644 & 1,518 & 0,471 & 0,715 \\
\hline Q35 & Strongly believes in fatalism & 1662 & 2,867 & 1,525 & 0,472 & 0,720 \\
\hline Q36 & Life influenced to a great extent by coincidences & 1662 & 3,195 & 1,455 & 0,529 & 0,770 \\
\hline Q38 & Other people are responsible for his/her wellbeing & 1662 & 3,581 & 1,437 & 0,360 & 0,518 \\
\hline Q41 & Convinced that failures in life could be attributed to fate & 1662 & 2,549 & 1,441 & 0,570 & 0,821 \\
\hline Q43 & Present achievements adversely affected by negative experiences in past & 1662 & 3,127 & 1,626 & 0,468 & 0,761 \\
\hline Q45 & Other people are in charge of his/her life and determine outcome of issues & 1662 & 2,505 & 1,359 & 0,536 & 0,729 \\
\hline Q47 & Convinced that a person cannot achieve without the right opportunities & 1662 & 4,619 & 1,445 & 0,366 & 0,529 \\
\hline Q50 & Convinced that success depends mainly upon equal opportunities in life & 1662 & 4,757 & 1,376 & $* * * *$ & $* * * *$ \\
\hline Q51 & Advancement in life is determined by your superiors & 1662 & 3,652 & 1,375 & 0,496 & 0,683 \\
\hline Q52 & Parents/guardians negatively influenced his/her achievement at school & 1662 & 2,142 & 1,467 & 0,391 & 0,574 \\
\hline Q53 & $\begin{array}{l}\text { Present achievement negatively influenced by people who are not } \\
\text { favourably disposed towards him/her }\end{array}$ & 1662 & 2,172 & 1,304 & 0,485 & 0,632 \\
\hline Q56 & $\begin{array}{l}\text { His/her progress in the past thwarted by people that were hostile towards } \\
\text { him/her }\end{array}$ & 1662 & 3,035 & 1,498 & 0,462 & 0,692 \\
\hline Q57 & $\begin{array}{l}\text { Convinced that only people who are at the right place at the right time } \\
\text { get promoted }\end{array}$ & 1662 & 3,282 & 1,465 & 0,569 & 0,833 \\
\hline Q58 & Only people who belong to the right political party have a chance in life & 1662 & 2,342 & 1,564 & 0,484 & 0,757 \\
\hline Q65 & $\begin{array}{l}\text { Convinced that clique formation is the most important determinant of } \\
\text { social acceptance }\end{array}$ & 1662 & 3,710 & 1,676 & 0,398 & 0,668 \\
\hline Q77 & $\begin{array}{l}\text { Convinced that promotion in the new South Africa will depend largely } \\
\text { on skin-colour }\end{array}$ & 1662 & 4,306 & 1,784 & 0,423 & 0,755 \\
\hline Q78 & Convinced that it is impossible to rise above your own environment & 1662 & 2,936 & 1,690 & 0,344 & 0,582 \\
\hline Q79 & $\begin{array}{l}\text { Convinced that his/her fate is determined by coincidental events over } \\
\text { which he/she has no control }\end{array}$ & 1662 & 2,690 & 1,463 & 0,611 & 0,894 \\
\hline Q80 & $\begin{array}{l}\text { Convinced that his/her advancement in life will be determined by certain } \\
\text { influential people }\end{array}$ & 1662 & 3,634 & 1,541 & 0,540 & 0,831 \\
\hline
\end{tabular}

MEANS AND STANDARD DEVIATIONS OF ITEM STATISTICS (ONLY IN RESPECT OF ITEMS INCLUDED IN TEST SCORE)

\begin{tabular}{llccc}
\hline & $\overline{\mathbf{X}}_{\mathrm{g}}$ & $\mathbf{s}_{\mathrm{g}}$ & $\mathbf{r}_{\mathrm{gx}}$ & $\mathbf{r}_{\mathrm{gx}} \mathbf{s}_{\mathrm{g}}$ \\
\hline Mean & 3,189 & 1,494 & 0,459 & 0,683 \\
SD & 0,736 & 0,141 & 0,080 & 0,120 \\
\hline Cronbach alpha & $=0,841$ & & & \\
Mean of test & $=79,730$ & & & \\
Standard deviation & $=17,079$ & & & \\
Number of items & $=25$ & & &
\end{tabular}


TABLE 20

ITEM STATISTICS IN RESPECT OF SCALE II OF THE LCI: INTERNAL CONTROL

\begin{tabular}{|c|c|c|c|c|c|c|}
\hline & DESCRIPTION OF ITEM & $\mathbf{N}$ & $\begin{array}{l}\text { MEAN OF } \\
\text { ITEM } \\
\left(\bar{X}_{\mathrm{g}}\right)\end{array}$ & $\begin{array}{l}\text { STANDARD } \\
\text { DEVIATION } \\
\text { OF ITEM } \\
\left(s_{g}\right)\end{array}$ & $\begin{array}{c}\text { ITEM-TEST } \\
\text { CORRELATION } \\
\left(\mathbf{r}_{\mathrm{gx}}\right)\end{array}$ & $\begin{array}{c}\text { INDEX OF } \\
\text { RELIABILITY } \\
\text { OF ITEM } \\
\left(\mathrm{r}_{\mathrm{gx}} \mathbf{s}_{\mathrm{g}}\right)\end{array}$ \\
\hline A6 & $\begin{array}{l}\text { Convinced that personal insight is a pre-requisite for good interpersonal } \\
\text { relationships }\end{array}$ & 1662 & 5,686 & 1,096 & 0,458 & 0,502 \\
\hline A7 & $\begin{array}{l}\text { The structure and routine of a person's work should be determined by } \\
\text { himself/herself }\end{array}$ & 1662 & 5,664 & 1,045 & 0,465 & 0,486 \\
\hline A8 & Readily accepts responsibility for mistakes that appear in his/her work & 1662 & 5,607 & 1,149 & 0,386 & 0,444 \\
\hline A10 & Convinced that success is mainly related to a person's ability and dedication & 1662 & 6,126 & 0,930 & 0,475 & 0,442 \\
\hline A16 & $\begin{array}{l}\text { Decides on matters himself/herself, rather than waiting for others to take } \\
\text { decisions on his/her behalf }\end{array}$ & 1662 & 5,180 & 1,619 & 0,343 & 0,556 \\
\hline A18 & Recognition encourages him/her to perform even better & 1662 & 6,063 & 1,018 & 0,461 & 0,470 \\
\hline A19 & Success encourages him/her to work harder and achieve greater heights & 1662 & 6,329 & 0,854 & 0,525 & 0,448 \\
\hline A25 & $\begin{array}{l}\text { Prefers to follow his/her own mind, rather than following someone else's } \\
\text { instructions }\end{array}$ & 1662 & 5,274 & 1,303 & 0,389 & 0,507 \\
\hline A26 & Insists on recognition of his/her own individual achievements & 1662 & 4,655 & 1,571 & 0,301 & 0,473 \\
\hline A27 & Takes responsibility for his/her own intellectual development & 1662 & 5,623 & 1,088 & 0,483 & 0,526 \\
\hline A31 & $\begin{array}{l}\text { Important for him/her to receive feedback on tasks which he/she has } \\
\text { performed }\end{array}$ & 1662 & 5,821 & 1,122 & 0,471 & 0,528 \\
\hline A32 & Convinced that reward for achievement is earned & 1662 & 5,252 & 1,234 & 0,454 & 0,560 \\
\hline A37 & Convinced that achievement of personal objectives depends on oneself & 1662 & 5,954 & 1,043 & 0,539 & 0,562 \\
\hline A40 & Readily accepts responsibility for his/her own poor performance & 1662 & 5,306 & 1,329 & 0,407 & 0,541 \\
\hline A42 & $\begin{array}{l}\text { Convinced that the respect one receives is directly related to one's } \\
\text { behaviour }\end{array}$ & 1662 & 6,100 & 1,059 & 0,538 & 0,570 \\
\hline A48 & Agrees that failure in life can be attributed to a lack of dedication & 1662 & 5,354 & 1,303 & 0,392 & 0,511 \\
\hline A49 & Convinced that success depends mainly on hard work & 1662 & 6,220 & 0,899 & 0,515 & 0,463 \\
\hline A54 & Takes personal responsibility for things that go wrong in his/her life & 1662 & 5,427 & 1,177 & 0,427 & 0,503 \\
\hline A55 & Convinced that the outcome of matters is determined by his/her own inputs & 1662 & 5,589 & 1,000 & 0,585 & 0,585 \\
\hline *A59 & Believes that his/her own input bears no relation to the outcome of matters & 1662 & 5,744 & 1,351 & 0,390 & 0,527 \\
\hline A60 & $\begin{array}{l}\text { Convinced that achievement depends upon his/her utilising his/her } \\
\text { God-given talents to the full }\end{array}$ & 1662 & 6,133 & 1,120 & 0,446 & 0,499 \\
\hline A61 & Convinced that the achievements he/she has obtained were deserved & 1662 & 5,968 & 1,131 & 0,490 & 0,554 \\
\hline A63 & Convinced that promotions are earned through hard work and perseverance & 1662 & 6,194 & 0,900 & 0,483 & 0,434 \\
\hline A69 & Convinced that he/she is sufficiently qualified for the work he/she is doing & 1662 & 5,742 & 1,107 & 0,493 & 0,546 \\
\hline A75 & $\begin{array}{l}\text { Convinced that the achievements he/she has obtained are the results of } \\
\text { hard work and dedication }\end{array}$ & 1662 & 5,969 & 1,087 & 0,552 & 0,600 \\
\hline A76 & Convinced that failures in life are due to a lack of perseverance & 1662 & 5,023 & 1,519 & 0,356 & 0,541 \\
\hline
\end{tabular}

MEANS AND STANDARD DEVIATIONS OF ITEM STATISTICS (ONLY IN RESPECT OF ITEMS INCLUDED IN TEST SCORE)

\begin{tabular}{llccc}
\hline & $\bar{X}_{\mathrm{g}}$ & $\mathbf{s}_{\mathrm{g}}$ & $\mathbf{r}_{\mathrm{gx}}$ & $\mathbf{r}_{\mathrm{gx}} \mathbf{s}_{\mathrm{g}}$ \\
\hline Mean & 5,692 & 1,156 & 0,455 & 0,515 \\
SD & 0,418 & 0,201 & 0,069 & 0,047 \\
\hline Cronbach alpha & $=0,832$ & & & \\
Mean of test & $=148,001$ & & & \\
Standard deviation & $=13,359$ & & & \\
Number of items & $=26$ & &
\end{tabular}


TABLE 21

ITEM STATISTICS IN RESPECT OF SCALE III OF THE LCI: AUTONOMY

\begin{tabular}{|c|c|c|c|c|c|c|}
\hline & DESCRIPTION OF ITEM & $\mathbf{N}$ & $\begin{array}{l}\text { MEAN OF } \\
\text { ITEM } \\
\left(\bar{X}_{\mathrm{g}}\right)\end{array}$ & $\begin{array}{l}\text { STANDARD } \\
\text { DEVIATION } \\
\text { OF ITEM } \\
\left(s_{\mathrm{g}}\right)\end{array}$ & $\begin{array}{c}\text { ITEM-TEST } \\
\text { CORRELATION } \\
\left(\mathbf{r}_{\mathrm{gx}}\right)\end{array}$ & $\begin{array}{c}\text { INDEX OF } \\
\text { RELIABILITY } \\
\text { OF ITEM } \\
\left(\mathbf{r}_{\mathrm{gx}} \mathbf{s}_{\mathrm{g}}\right)\end{array}$ \\
\hline *Q1 & Doubts his/her own capabilities when his/her work is being criticised & 1662 & 4,796 & 1,372 & 0,468 & 0,642 \\
\hline Q2 & $\begin{array}{l}\text { Geared towards ensuring that his/her case triumphs during a conflict } \\
\text { situation }\end{array}$ & 1662 & 5,494 & 1,277 & 0,429 & 0,547 \\
\hline Q3 & Would readily take risks & 1662 & 4,500 & 1,363 & 0,370 & 0,505 \\
\hline Q5 & Can readily convince someone else of his/her viewpoint & 1662 & 5,256 & 1,017 & 0,559 & 0,569 \\
\hline Q13 & Convinced that he/she will succeed when undertaking important tasks & 1662 & 5,797 & 0,951 & 0,566 & 0,539 \\
\hline Q14 & $\begin{array}{l}\text { Makes things happen through his/her own input, rather than waiting for } \\
\text { things to happen }\end{array}$ & 1662 & 5,201 & 1,165 & 0,575 & 0,670 \\
\hline *Q15 & Waits for other people to take charge, rather than taking charge & 1662 & 4,691 & 1,503 & 0,543 & 0,816 \\
\hline Q17 & Failure spurs him/her on to improve his/her performance & 1662 & 5,315 & 1,288 & 0,392 & 0,505 \\
\hline Q22 & Likes taking decisions himself/herself & 1662 & 5,804 & 1,102 & 0,574 & 0,633 \\
\hline Q24 & Would readily air his/her views when they differ from someone else's & 1662 & 5,440 & 1,249 & 0,549 & 0,686 \\
\hline Q28 & Likes occupying a leadership position & 1662 & 5,463 & 1,366 & 0,533 & 0,728 \\
\hline Q29 & $\begin{array}{l}\text { Would stick to his/her viewpoint when someone for whom he/she has } \\
\text { great respect disagrees with him/her }\end{array}$ & 1662 & 5,288 & 1,211 & 0,494 & 0,598 \\
\hline Q30 & Likes solving complex problems & 1662 & 5,206 & 1,325 & 0,518 & 0,686 \\
\hline *Q39 & Feels that he/she has no control over his/her own circumstances & 1662 & 4,779 & 1,400 & 0,407 & 0,570 \\
\hline Q44 & Often achieves set objectives, irrespective of the conditions & 1662 & 5,187 & 1,023 & 0,533 & 0,545 \\
\hline Q46 & $\begin{array}{l}\text { Convinced that he/she can solve most problems, irrespective of the } \\
\text { conditions }\end{array}$ & 1662 & 5,400 & 1,113 & 0,504 & 0,561 \\
\hline Q62 & Can predict the outcome of an examination he/she has just written & 1662 & 5,623 & 1,205 & 0,335 & 0,403 \\
\hline Q64 & Finds it easy to satisfy choosy people & 1662 & 4,345 & 1,296 & 0,381 & 0,494 \\
\hline Q66 & $\begin{array}{l}\text { Convinced that he/she possesses the ability to produce work of the highest } \\
\text { quality }\end{array}$ & 1662 & 6,090 & 0,902 & 0,517 & 0,466 \\
\hline Q67 & $\begin{array}{l}\text { Would strongly defend his/her actions if the appropriateness thereof were to } \\
\text { be questioned by others }\end{array}$ & 1662 & 5,764 & 1,055 & 0,517 & 0,545 \\
\hline Q68 & $\begin{array}{l}\text { Convinced that he/she is sufficiently qualified for the work that he/she is } \\
\text { doing }\end{array}$ & 1662 & 5,739 & 1,007 & 0,546 & 0,550 \\
\hline Q70 & Prefers challenging work to routine work & 1662 & 5,649 & 1,217 & 0,518 & 0,630 \\
\hline *Q71 & Subsequently doubts the correctness of the decisions he/she has taken & 1662 & 4,430 & 1,292 & 0,433 & 0,559 \\
\hline${ }^{*} \mathrm{Q} 72$ & Dependent on the support and goodwill of others in the execution of tasks & 1662 & 4,294 & 1,337 & 0,365 & 0,488 \\
\hline *Q73 & Would readily quit if he/she is battling with a complex problem & 1662 & 5,199 & 1,282 & 0,483 & 0,619 \\
\hline Q74 & Often takes the initiative in finding solutions for troublesome problems & 1662 & 5,210 & 1,129 & 0,575 & 0,649 \\
\hline
\end{tabular}

MEANS AND STANDARD DEVIATIONS OF ITEM STATISTICS (ONLY IN RESPECT OF ITEMS INCLUDED IN TEST SCORE)

\begin{tabular}{llccc}
\hline & $\overline{\mathbf{X}}_{\mathrm{g}}$ & $\mathbf{s}_{\mathrm{g}}$ & $\mathbf{r}_{\mathrm{gx}}$ & $\mathbf{r}_{\mathrm{gx}} \mathbf{s}_{\mathrm{g}}$ \\
\hline Mean & 5,229 & 1,210 & 0,488 & 0,585 \\
SD & 0,489 & 0,153 & 0,074 & 0,090 \\
\hline Cronbach alpha & $=0,866$ & & & \\
Mean of test & $=135,958$ & & & \\
Standard deviation & $=15,189$ & & & \\
Number of items & $=26$ & &
\end{tabular}




\section{DISCUSSION}

From the findings of the study it is clear that the degree of skewness (marginal splits) of binary items places an upper limit on the correlations between the items. Furthermore, intercorrelation matrices based on such items, arranged according to their degree of skewness, have the typical structure of a simplex, quasi-simplex or pseudosimplex. Factoring such matrices result in factors of skewness, regardless of the contents of the items.

As far as the first objective of the study is concerned, it was found that similar gradients exist in respect of the correlations in an intercorrelation matrix based on continuous variables, arranged in terms of skewness.

To achieve the second objective, the items of the LCI were grouped into parcels of four items each. The parcels were intercorrelated and subjected to factor analysis. Three factors were obtained. These factors were also largely factors of skewness. Content also played a role in so far as the contents of the items were associated with their degree of skewness. The items loading on Factors I and III (Autonomy and Internal Control) are essentially negatively skewed, whereas those loading on Factor II (External Control) are positively skewed.

As far as the third and major objective of the study is concerned, the procedure that was followed, yielded three factors that were well determined. The corresponding scales that were produced are internally highly consistent, with reliabilities that range from 0,832 to 0,866 .

Autonomy is positively correlated with Internal Control $(\mathrm{r}=$ $0,438 ; \mathrm{p}<0,001)$. There is thus approximately $19 \%$ common variance between the two constructs. However, the reliable variance of Autonomy is $87 \%$ and that of Internal Control $83 \%$. The specific variances of the two scales therefore vary from $64 \%$ to $68 \%$

Autonomy and External Control are negatively correlated $(\mathrm{r}=-0,393 ; \mathrm{p}<0,001)$. There is thus approximately $15 \%$ common variance between the two constructs. The reliable variance of External Control is $84 \%$. The specific variances of the two constructs (scales) therefore vary from $69 \%$ to $72 \%$.

Internal Control and External Control are essentially uncorrelated $(r=-0,018 ; p>0,05)$. This is in keeping with Social Learning Theory and Attribution Theory: The causes of human behaviour can be divided into two broad classes, namely those that pertain to one's natural disposition and those that pertain to the external world (Roediger III et al., 1991). It is therefore not surprising that items from these two domains are essentially independent of one another.

In the procedure followed in the present study, the items were grouped according to the factors they loaded on. Each subscore was therefore internally consistent. The fact that a Varimax rotation was used, kept the factors relatively independent of one another, and simplified the procedure. In intercorrelating the items of the LCI both content and degree of skewness of the items must have played a role. However, the degree of skewness of the subtests are considerably smaller than those of the single items.

Forming parcels on a priori theoretical grounds does not guarantee internal consistency within parcels or eliminate the effects of differential skewness completely. For this, a new measure of association that is independent of skewness, is required.

The procedure described, has been used at the Rand Afrikaans University since 1992, and has consistently produced scales of high reliability and validity.

\section{ACKNOWLEDGEMENTS}

I hereby wish to thank all the members of the Statistical Consultation Service of the Rand Afrikaans University for all the hours of computational work done for me. I value it very highly.

A special word of thanks to Annetjie Boshoff for the typing of the manuscript. Nobody can type tables better than her.

\section{REFERENCES}

Baron, R.A., Byrne, D. \& Kantowitz, B.H. (1980). Understanding behavior (2nd ed.) New York: Holt, Rinehart and Winston.

Bohrnstedt, G.W. \& Knoke, D. (1988). Statistics for social data analysis (2nd ed.) Itasca, Ill.: F.E. Peacock Publishers, Inc.

Cronbach, L.J. (1951). Coefficient alpha and the internal structure of tests. Psychometrika, 16, 297-334.

Ferguson, G.A. (1941). The factorial interpretation of test difficulty. Psychometrika, 6, 323-329.

Gorsuch, R.L. (1974). Factor analysis. Philadelphia: W.B. Saunders Company.

Guilford, J.P. (1950). Fundamental statistics in psychology and education (2nd ed.) New York: McGraw-Hill.

Guttman, L.A. (1954). A new approach to factor analysis: the radex. In: Lazarsfeld, P.F. (Ed.): Mathematical thinking in the social sciences. Glencoe, Ill: The Free Press.

Guttman, L.A. (1955). A generalized simplex for factor analysis. Psychometrika, 20, 173-192

Guttman, L.A. (1957). Empirical verification of the radex structure of mental abilities and personality traits. Educational and Psychological Measurement, 17, 391-407.

Horst, P. (1953). Correcting the Kuder-Richardson reliability for dispersion of item difficulties. Psychological Bulletin, 50, 371-374.

Horst, P. (1965). Factor analysis of data matrices. New York: Holt, Rinehart and Winston.

Jöreskog, K.G. (1970). Estimation and testing of simplex models. British Journal of Mathematical and Statistical Psychology, 23, 121-145.

Jöreskog, K.G. \& Sorbom, D. (1982). LISREL V: Analysis of linear structural relationships by maximum likelihood and least squares. Uppsala, Sweden: University of Uppsala.

Kaiser, H.F. (1961). A note on Guttman's lower bound for the number of common factors. British Journal of Statistical Psychology, 14 (1), 1.

Kuder, G.F. \& Richardson, M.W. (1937). The theory of the estimation of test reliability. Psychometrika, 2, 151-160.

Magnusson, D. (1967). Test theory. Reading Mass.: AddisonWesley.

Mischel, W. (1979). On the interface of cognition and personality: Beyond the person-situation debate. American Psychologist, 34, 740-754.

Roediger III, H.L., Capaldi, E.D., Paris, S.G. \& Polivy, J. (1991). Psychology (3rd ed.) New York: Harper Collins Publishers.

Rotter, J.B. (1966). Generalized expectancies for internal versus external control of reinforcement. Psychological Monographs, 80, No 1 (Whole No. 609).

Schepers, J.M. (1962). A components analysis of a complex psychomotor learning task. Psychologia Africana, 9, 294-329.

Schepers, J.M. (1992). Toetskonstruksie: Teorie en praktyk. Johannesburg: RAU-Drukpers.

Schepers, J.M. (1995). The Locus of Control Inventory (revised edition). Johannesburg.

Tucker, L.R. (1949). A note on the estimation of test reliability by the Kuder-Richardson Formula (20). Psychometrika, 14, 117-119.

Wolman, B.B. (1973). Dictionary of behavioral science. New York: Van Nostrand Reinhold Company. 


\section{APPENDIX 1}

Cronbach's coefficient alpha and Kuder-Richardson Formula 20 (KR20), for continuous data, are formally the same, and can be written as follows:

$K R_{20}=\frac{K}{K-1}\left[1-\frac{\sum_{g=1}^{K} \sigma_{g}^{2}}{\sigma_{x}^{2}}\right]$, where

$K=$ number of test items

$\sum \sigma_{g}^{2}=$ sum of item variances

$\sigma_{g}^{2}=$ test variance

For binary data $K R_{20}$ can be written as follows:

$K R_{20}=\frac{K}{K-1}\left[1-\frac{\sum_{g=1}^{K}\left(p_{g}-p_{g}^{2}\right)}{\sigma_{x}^{2}}\right]$, where

$K=$ number of test items

$p_{g}=$ proportion of subjects endorsing item $g$ according to the key

The variance of the p-values can be written as

$$
\begin{aligned}
\sigma_{p}^{2} & =\frac{\sum_{g=1}^{K}\left(p_{g}-\bar{p}\right)^{2}}{K}, \\
& =\frac{\sum p_{g}^{2}}{K}-\bar{p}^{2}
\end{aligned}
$$

From this it follows that

$\sum_{g=1}^{K} p_{g}^{2}=K\left(\sigma_{p}^{2}+\bar{p}^{2}\right)$

Substitution for $\sum_{g=1}^{K} p_{g}^{2}$ in (2) gives

$K R_{20}=\frac{K}{K-1}\left[1-\frac{\sum_{g=1}^{K} p_{g}-K\left(\sigma_{p}^{2}+\bar{p}^{2}\right)}{\sigma_{x}^{2}}\right]$,

$$
=\frac{K}{K-1}\left[1-\frac{\mu-K\left(\sigma_{p}^{2}+\frac{\mu^{2}}{K^{2}}\right.}{\sigma_{x}^{2}}\right] \text {, }
$$

Because $\sum_{g=1}^{K} p_{g}^{2}=\mu$ (mean of test)

and $\bar{p}=\frac{\mu}{K}$

$\therefore K R_{20}=\frac{K}{K-1}\left[1-\frac{\mu-\frac{\mu^{2}}{K}-K \sigma_{p}^{2}}{\sigma_{x}^{2}}\right]$

Formula 6 applies only to binary data.

For continuous data Kuder-Richardson Formula 20 and Cronbach's coefficient alpha can be written as follows:

$K R_{20}=\frac{K}{K-1}\left[1-\frac{\sum \sigma_{g}^{2}}{\sigma_{x}^{2}}\right]$, where

$K=$ number of test items

$\sum \sigma_{g}^{2}=$ sum of item variances

$\sigma_{x}^{2}=$ test variance

Formula 7 can be transformed as follows:

$K R_{20}=\frac{K}{K-1}\left[1-\frac{1}{K}-\frac{\sum_{g=1}^{K} \sigma_{g}^{2}}{\sigma_{x}^{2}}+\frac{1}{K}\right]$

$$
\begin{aligned}
& =\left[1-\frac{\left(K \sum_{g=1}^{K} \sigma_{g}^{2}-\sigma_{x}^{2}\right)}{(K-1) \sigma_{x}^{2}}\right], \\
& =\left[1-\frac{K \sum_{g=1}^{K} \sigma_{g}^{2}-\sigma_{x}^{2}}{(K-1) \sigma_{x}^{2}}\right],
\end{aligned}
$$

The total test variance can never exceed $K \sum_{g=1}^{K} \sigma_{g}^{2}$ therefore the greater the test variance, the higher the reliability (Schepers, 1992, p. 33). 


\section{APPENDIX 2}

PHI COEFFICIENT IN RESPECT OF BINARY TEST ITEMS

\begin{tabular}{|c|c|c|c|}
\hline & + & - & Total \\
\hline \multirow[t]{4}{*}{ - } & A & B & $A+B$ \\
\hline & 30 & 20 & 50 \\
\hline & (40) & (10) & (50) \\
\hline & & & $\mathrm{q}_{\mathrm{k}}=0,5$ \\
\hline \multirow{4}{*}{+} & C & D & $C+D$ \\
\hline & 10 & 40 & 50 \\
\hline & (0) & (50) & $(50)$ \\
\hline & & & $\mathrm{p}_{\mathrm{k}}=0,5$ \\
\hline \multirow[t]{4}{*}{ Total } & $\mathrm{A}+\mathrm{C}$ & $B+D$ & $\mathrm{~N}$ \\
\hline & 40 & 60 & 100 \\
\hline & (40) & (60) & (100) \\
\hline & $\mathrm{p}_{\mathrm{g}}=0,4$ & $\mathrm{q}_{\mathrm{g}}=0,6$ & \\
\hline
\end{tabular}

$r_{p h i}=\frac{p_{g k}-p_{g} p_{k}}{\sqrt{p_{g} q_{g} p_{k} q_{k}}}$

$=\frac{p_{g k}-0,4 \times 0,5}{\sqrt{0,4 \times 0,6 \times 0,5 \times 05}}=\frac{0,10-0,20}{0,244948974}$

$=-0,40824829$

$\phi=\frac{B C-A D}{\sqrt{(A+B)(C+D)(A+C)(B+D)}}$

$=\frac{200-1200}{2449,489743}$

$=-0,40824829 \Rightarrow$

Maximum value of $\phi$

Set $C=0$, then

$\phi=\frac{0-2000}{2449,489743}$

$=-0,81649658 \Rightarrow$ phi $=\frac{p_{g k}-p_{g} p_{k}}{\sqrt{p_{g} q_{g} p_{k} q_{k}}}$

$=\frac{0,4-0,4 \times 0,5}{\sqrt{0,4 \times 0,6 \times 0,5 \times 0,5}}$

$=\frac{0,20}{0,244948974}$

$=0,81649658 \Rightarrow$

$\phi=\frac{p_{g k}-p_{g} p_{k}}{\sqrt{p_{g} q_{g} p_{k} q_{k}}}$

To obtain $\phi_{\max }$, set $p_{g k}=p_{g}$, where $p_{g} \leq p_{k}$

$\phi_{\max }=\frac{p_{g}-p_{g} p_{k}}{\sqrt{p_{g} q_{g} p_{k} q_{k}}}$

$=\frac{p_{g}\left(1-p_{k}\right)}{\sqrt{p_{g} q_{g} p_{k} q_{k}}}$

$=\frac{p_{g} q_{k}}{\sqrt{p_{g} q_{g} p_{k} q_{k}}}$

$\phi_{\max }^{2}=\frac{p_{g}^{2} q_{k}^{2}}{p_{g} q_{g} p_{k} q_{k}}$

$\phi_{\max }=\sqrt{\frac{p_{g} q_{k}}{q_{g} p_{k}}}$

$$
=\sqrt{\left(\frac{p_{g}}{q_{g}}\right)}\left(\frac{q_{k}}{p_{k}}\right)
$$

Note that the maximum value of $\phi$ is a direct function of the marginal splits $\left(p_{g} \mid q_{g}\right.$ and $\left.q_{k} \mid p_{k}\right)$.

Example

$\phi_{\max }=\sqrt{\left(\frac{0,4}{0,6}\right)\left(\frac{0,5}{0,5}\right)}=\sqrt{\frac{0,20}{0,30}}=0,81649658$ 